\title{
Modified strontium titanates: From defect chemistry to SOFC anodes
}

Verbraeken, M.C.; Ramos, Tania; Agersted, Karsten; Ma, Q.; Savaniu, C.D.; Sudireddy, Bhaskar Reddy; Irvine, J.T.S.; Holtappels, Peter; Tietz, F.

\section{Published in:}

RSC Advances

Link to article, DOI:

$10.1039 / \mathrm{c} 4 \mathrm{ra} 09751 \mathrm{c}$

Publication date:

2015

Document Version

Publisher's PDF, also known as Version of record

Link back to DTU Orbit

Citation (APA):

Verbraeken, M. C., Ramos, T., Agersted, K., Ma, Q., Savaniu, C. D., Sudireddy, B. R., Irvine, J. T. S.,

Holtappels, P., \& Tietz, F. (2015). Modified strontium titanates: From defect chemistry to SOFC anodes. RSC Advances, 5(2), 1168-1180. https://doi.org/10.1039/c4ra09751c

\section{General rights}

Copyright and moral rights for the publications made accessible in the public portal are retained by the authors and/or other copyright owners and it is a condition of accessing publications that users recognise and abide by the legal requirements associated with these rights.

- Users may download and print one copy of any publication from the public portal for the purpose of private study or research.

- You may not further distribute the material or use it for any profit-making activity or commercial gain

- You may freely distribute the URL identifying the publication in the public portal 


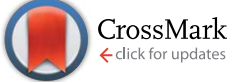

Cite this: RSC Adv., 2015, 5, 1168

\title{
Modified strontium titanates: from defect chemistry to SOFC anodes
}

\author{
M. C. Verbraeken, ${ }^{\star a}$ T. Ramos, ${ }^{b}$ K. Agersted, ${ }^{b}$ Q. Ma, ${ }^{c}$ C. D. Savaniu, ${ }^{a}$ B. R. Sudireddy, ${ }^{b}$ \\ J. T. S. Irvine, ${ }^{a}$ P. Holtappels ${ }^{b}$ and F. Tietz ${ }^{c}$
}

Modified strontium titanates have received much attention recently for their potential as anode material in solid oxide fuel cells (SOFC). Their inherent redox stability and superior tolerance to sulphur poisoning and coking as compared to Ni based cermet anodes could improve durability of SOFC systems dramatically. Various substitution strategies can be deployed to optimise materials properties in these strontium titanates, such as electronic conductivity, electrocatalytic activity, chemical stability and sinterability, and thus mechanical strength. Substitution strategies not only cover choice and amount of substituent, but also perovskite defect chemistry, distinguishing between $A$-site deficiency $\left(A_{1-x} B_{3}\right)$ and cationstoichiometry $\left(\mathrm{ABO}_{3+\delta}\right)$. Literature suggests distinct differences in the materials properties between the latter two compositional approaches. After discussing the defect chemistry of modified strontium titanates, this paper reviews three different A-site deficient donor ( $\mathrm{La}, \mathrm{Y}, \mathrm{Nb}$ ) substituted strontium titanates for their electrical behaviour and fuel cell performance. Promising performances in both electrolyte as well as anode supported cell designs have been obtained, when using hydrogen as fuel. Performances are retained after numerous redox cycles. Long term stability in sulphur and carbon containing fuels still needs to be explored in greater detail.

Received 3rd September 2014 Accepted 26th November 2014

DOI: 10.1039/c4ra09751c

www.rsc.org/advances instability upon redox cycling (cyclic reduction and oxidation). ${ }^{\mathbf{1 0}}$ These provide the motivation for developing an alternative, more robust anode. In this light, ceramic anodes have received increased interest, as they are expected to be less prone to the typical issues associated with $\mathrm{Ni}$ based anodes. Perovskite materials containing transition metals (e.g. Ti, Nb, V, Co, Mn, Mo, etc.) are of particular interest due to the availability of multiple oxidation states, higher tolerance to coking and poisoning, and good dimensional stability upon redox cycling. ${ }^{\mathbf{1 1}}$ These types of materials have inherently limited electronic conductivity however, which is a major drawback. Currently it is believed that the minimum requirement for electronic conductivity in SOFC anode materials should be at least 10-100 $\mathrm{S} \mathrm{cm}^{-1}$; this may have to be even higher when using an anode supported cell design. ${ }^{\mathbf{1 2 , 1 3}}$

Within the vast family of perovskite materials, $\mathrm{SrTiO}_{3}$ based compounds have attracted particular attention over the past years, due to their decent n-type conductivity and good stability in various atmospheres. This work aims to review the latest developments in material design of such $\mathrm{SrTiO}_{3}$ based anodes, with special emphasis on substitution with lanthanum (LST), yttrium (YST) and niobium (STN), covering important topics such as defect chemistry, electrical properties, as well as their performance as potential SOFC anode materials.

\footnotetext{
${ }^{a}$ School of Chemistry, University of St Andrews, North Haugh, St Andrews, KY16 9ST, UK. E-mail: mcv3@st-andrews.ac.uk

${ }^{b}$ DTU Energy Conversion and Storage, Technical University of Denmark, Frederiksborgvej 399, DK-4000 Roskilde, Denmark

${ }^{c}$ Forschungszentrum Jülich GmbH, Institut für Energieforschung (IEK-1), DE-52425 Jülich, Germany
} 


\section{Defect chemistry of modified $\mathrm{SrTiO}_{3}$}

The effectiveness of ceramic electrodes in SOFC depends on an intricate interplay between the material's crystal structure and defect chemistry. Especially materials containing transition metals are of interest, since the availability of multiple oxidation states can facilitate bulk transport properties, and provide mechanisms for electrocatalytic processes. For example, under reducing atmospheres the transition metal ions change to lower oxidation states, effectively creating electronic carriers to pass current. Also, the formation of oxygen vacancies on reduction is likely to yield an increase in the oxide ion conductivity according to eqn (1), in Kröger-Vink notation:

$$
\mathrm{O}_{\mathrm{O}}^{\times} \rightleftarrows 2 \mathrm{e}^{\prime}+\mathrm{V}_{\mathrm{O}}^{*}+\frac{1}{2} \mathrm{O}_{2}(\mathrm{~g})
$$

Perovskite materials have received much attention as potential anodes for SOFC, due to their adaptable defect chemistry through compositional tailoring. In particular aliovalent substitution, i.e. exchange of $\mathrm{ABO}_{3}$ cations with similar sized cations of different valence, is an effective way to introduce defects, control defect concentrations and hence tailor anode functionality. For instance, A-site vacancies can be introduced by substitution of A-site ions with cations of higher valence (donors) giving compounds of stoichiometry of $\mathrm{A}_{(1-x-y)} \mathrm{A}_{x}^{\prime} \mathrm{BO}_{3}$, while the substitution of A-site ions with lower valence cations (acceptors) could be used to introduce oxygen vacancies, giving compounds of stoichiometry $\mathrm{A}_{(1-x)} \mathrm{A}_{x}^{\prime} \mathrm{BO}_{(3-\delta)}$ if the B-site valence remains constant. ${ }^{14}$ Alternatively, acceptor or donor-substitution can also be performed on the B-site, with the most important criterion for a possible substitution of A- or Bsite ions by dopants being the ionic radius of the considered species.

Strontium titanate $\left(\mathrm{SrTiO}_{3}\right)$ is an excellent example of a perovskite exhibiting a wide range of defect chemistry that can illustrate the influence of different factors on conductivity. Due to the reducibility of $\mathrm{Ti}^{4+}$ to $\mathrm{Ti}^{3+}$ it exhibits n-type semiconducting behaviour in reducing atmospheres. Introducing donor and/or acceptor defects has shown to be an effective way of modifying the oxygen and cation content in the perovskite structure, thereby altering the material's conductivity behaviour under various atmospheres..$^{15,16}$

To fully appreciate the various defect chemistries in modified $\mathrm{SrTiO}_{3}$ and their effect on the material's electrical properties, it is important to first discuss the effect of donor and acceptor substitution under oxidising conditions.

\section{Cation and oxygen stoichiometric $\mathrm{SrTiO}_{3}$}

Due to different defect chemistries achievable in strontium titanates, ambiguities arise in literature as to the nature of the non-stoichiometry, since this is not always evident from the composition alone. For this reason, Savaniu and Irvine have proposed a new oxide nomenclature to describe these perovskite phase compositions. ${ }^{17}$ The oxides are represented using normal case capital letters corresponding to the present cations, the oxide composition being normalized to one cation per formula unit, e.g. $\mathrm{LaO}_{1.5} \rightarrow \mathrm{L}$, SrO $\rightarrow \mathrm{S}$, $\mathrm{TiO}_{2} \rightarrow \mathrm{T}$, $\mathrm{NbO}_{2.5} \rightarrow \mathrm{N}$, etc. The deviation from the $\mathrm{ABO}_{3}$ stoichiometry is marked as a final subscript, for example ${ }_{A^{-}}$for A-site deficiency, o+ for oxygen excess and so on.

Many reports and reviews on modified $\mathrm{SrTiO}_{3}$ focus on cation-stoichiometric perovskites. This is an important distinction (as compared to A-site deficient perovskites), which is sometimes overlooked in literature. Acceptor (A) or donor (D) substitution may affect the oxygen stoichiometry according to eqn (2) and (3) (substitution arbitrarily chosen on B- and A-site, respectively). It has been argued that interstitial oxygen is highly unlikely in the densely packed perovskite lattice. ${ }^{15}$ Therefore the excess oxygen is rather expected to be accommodated in secondary SrO phases or oxygen rich extended defects. ${ }^{18-20}$ In turn it has generally been accepted that eqn (4) is more correct in these materials, whereby the positive charge of the donor is compensated by strontium vacancies.

$$
\begin{gathered}
\mathrm{AO} \stackrel{\mathrm{SrTiO}_{3}}{\longrightarrow} \mathrm{A}_{\mathrm{Ti}}^{\prime \prime}+\mathrm{V}_{\mathrm{O}}^{\cdot} \\
\mathrm{D}_{2} \mathrm{O}_{3} \stackrel{\mathrm{SrTiO}_{3}}{\longrightarrow} 2 \mathrm{D}_{\mathrm{Sr}}^{\cdot}+\mathrm{O}_{\mathrm{i}}^{\prime \prime} \\
\mathrm{D}_{2} \mathrm{O}_{3} \stackrel{\mathrm{SrTiO}_{3}}{\longrightarrow} 2 \mathrm{D}_{\mathrm{Sr}}^{\cdot}+\mathrm{V}_{\mathrm{Sr}}^{\prime \prime}
\end{gathered}
$$

McColm and Irvine noticed that acceptor substitution on the B-site in fact results in a decrease in conductivity under reducing atmosphere.$^{16}$ However, a marked improvement of the p-type conductivity under oxidising conditions was noticed, suggesting that holes are the predominant compensation under these conditions. This can be explained by eqn (5), where intrinsic oxygen vacancies (created due to eqn (2)) are filled with ambient oxygen generating a pair of holes. It seems therefore that donor-substitution of $\mathrm{SrTiO}_{3}$ is the preferred strategy for making superior SOFC anode materials with good electrical properties under reducing conditions.

$$
\mathrm{V}_{\mathrm{O}}^{*}+\frac{1}{2} \mathrm{O}_{2} \rightleftarrows \mathrm{O}_{\mathrm{O}}^{\times}+2 \mathrm{~h}^{\cdot}
$$

Cation-stoichiometric titanates with nominal oxygen excess (e.g. $\mathrm{LST}_{\mathrm{O}^{+}}$) are of remarkable interest due to their very high electronic conductivity, the presence of extended defects rich in oxygen and high stability in reducing conditions. ${ }^{18,21}$ The presence of extra oxygen beyond the normal stoichiometry increases the ease and amount of reduction of $\mathrm{Ti}^{4+}$ to $\mathrm{Ti}^{3+}$, in turn increasing the conductivity. The oxygen excess plays a critical role in both the structural and electrochemical properties, although this is often ignored in the literature. On consideration of strontium titanate solid state chemistry, it is likely that for compositions such as $\mathrm{La}_{x} \mathrm{Sr}_{1-x} \mathrm{TiO}_{3+\delta}, \delta$ is generally positive and will only be nil or negative under very reducing conditions, probably more reducing than the actual fuel cell operating conditions. Flandermeyer et al. ${ }^{22}$ calculated, using thermogravimetric measurements, that up to an extra $x / 2$ moles of oxygen 
can be accommodated by $\mathrm{La}_{x} \mathrm{Sr}_{1-x} \mathrm{TiO}_{3+\delta}$ formula. It has been shown that the presence of disordered oxygen-rich defects affects to a great extent the redox characteristics of an oxide as indicated by very significant changes in conductivity under certain conditions. ${ }^{\mathbf{1 8 2 3}}$ The conductivity data indicate that oxygen excess compositions are more conductive than the ones presenting oxygen deficiency, at the same oxygen partial pressure. $^{\mathbf{2 4 , 2 5}}$

Alternative to being cation-stoichiometric, strontium titanates which are stoichiometric in oxygen have been developed. ${ }^{26}$ Here A-site cation vacancies are purposely introduced into the material's composition, which will now adopt the general formula $\mathrm{X}_{y} \mathrm{Sr}_{1-3 / 2 y} \mathrm{TiO}_{3}$, with $\mathrm{X}$ being a trivalent cation. Once again, strontium vacancies are the main compensating mechanism for the introduced donor, according to eqn (4). However, due to the large concentration of $\mathrm{V}_{\mathrm{Sr}}^{\prime \prime}$, the formation of intrinsic Schottky defects is now being reduced, pushing eqn (6) to the left and reducing $\left[\mathrm{V}_{\mathrm{O}} \cdot{ }^{*}\right.$. At any given oxygen partial pressure, eqn (1) now shifts to the right, facilitating oxygen removal from the perovskite lattice associated with the generation of free electrons.

$$
\mathrm{O}_{\mathrm{O}}^{\times}+\mathrm{A}_{\mathrm{A}}^{\times} \rightleftarrows \mathrm{AO}+\mathrm{V}_{\mathrm{O}}^{\cdot *}+\mathrm{V}_{\mathrm{A}}^{\prime \prime}
$$

\section{Titanium reduction}

To produce highly conductive anode materials based on modified $\mathrm{SrTiO}_{3}$, elevated temperatures and reducing atmospheres are required, either during the material preparation or prior to testing. A comprehensive review of the defect chemistry of cation-stoichiometric donor-substituted strontium titanates has been given by Moos and Härdtl. ${ }^{27}$ Fig. 1 shows the conductivity behaviour for this type of donor-substituted $\mathrm{SrTiO}_{3}$ versus $\mathrm{pO}_{2}$ for two different temperatures, $T_{1}$ and $T_{2}$. As mentioned earlier, in cation-stoichiometric donor-modified $\mathrm{SrTiO}_{3}$, the extra positive charge of the donor is either compensated by oxygen excess, or by A-site cation vacancies $\left(\mathrm{V}_{\mathrm{Sr}}^{\prime \prime}\right)$. This donor compensation mechanism means that under

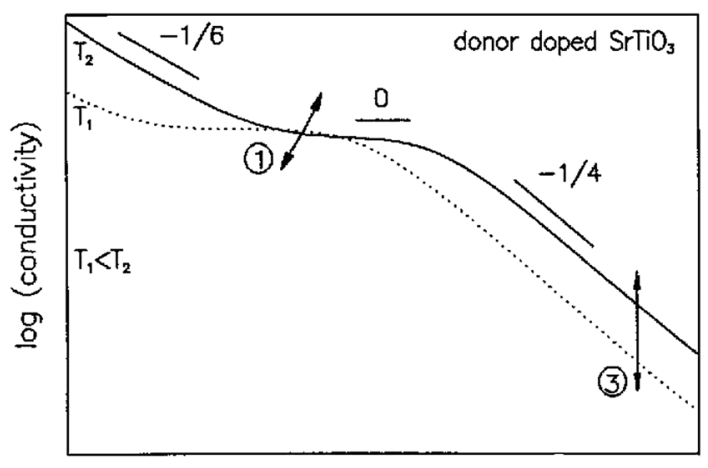

$\log$ (oxygen partial pressure)

Fig. 1 Log-log plots of the conductivity of modified $\mathrm{SrTiO}_{3}$ versus oxygen partial pressure $\left(\mathrm{pO}_{2}\right)$ representing donor-modified $\mathrm{SrTiO}_{3}$, with slopes of $-1 / 6,0$, and $-1 / 4$ in the low, intermediate, and high $\mathrm{pO}_{2}$ ranges, respectively. ${ }^{27}$ (Copyright @ 2005 , John Wiley and Sons.) mildly reducing conditions, Ti reduction is compensated by lowering of the oxygen excess or concentration of strontium vacancies, probably according to eqn (7). The SrO in this equation is likely to originate from a Ruddlesden-Popper phase or grain terminations.

$$
\mathrm{SrO}+\mathrm{V}_{\mathrm{Sr}}^{\prime \prime} \stackrel{\mathrm{H}_{2}}{\rightleftarrows} \mathrm{Sr}_{\mathrm{Sr}}^{\times}+2 \mathrm{e}^{\prime}+\frac{1}{2} \mathrm{O}_{2}(\mathrm{~g})
$$

It can easily be derived that under these conditions a $\mathrm{pO}_{2}{ }^{-1 / 4}$ dependence of the conductivity is to be expected. At intermediate $\mathrm{pO}_{2}$ values, extrinsic donor concentration, $\left[\mathrm{D}^{*}\right]$ dominates and conductivity is now dependent only on the donor concentration and the temperature-dependent mobility, but not on $\mathrm{pO}_{2}$. This region is therefore often called the "plateau region", or the region of electronic compensation.

It is only at very low $\mathrm{pO}_{2}$ values, where oxygen vacancies become the predominant ionic defect (eqn (1)), giving rise to a $\mathrm{pO}_{2}{ }^{-1 / 6}$ dependence of the conductivity. In terms of lattice oxygen stoichiometry, at high $\mathrm{pO}_{2}$ there will be excess oxygen, i.e. $\mathrm{A}_{1-x}^{\prime} \mathrm{A}_{x}^{\prime \prime} \mathrm{BO}_{3+\delta}$, with $\delta>0$; in the plateau region the perovskite will be oxygen stoichiometric, i.e. $\delta=0$; only at very low $\mathrm{pO}_{2}$ will $\delta$ become negative. Depending on composition and substituents, the $\mathrm{pO}_{2}$ at which $\delta$ is negative may even be beyond SOFC operating conditions.

In other words, for cation-stoichiometric donor substituted $\mathrm{SrTiO}_{3}$, titanium reduction is either compensated by a change in strontium vacancy concentration in oxidising atmospheres, or by the formation of oxygen vacancies under very reducing conditions. The substitution strategy and donor concentration determines the initial strontium vacancy concentration, effectively enhancing the reducibility of titanium, thereby increasing the charge carrier concentration.

The situation is expected to be different for A-site deficient donor substituted strontium titanates, owing to a different oxygen stoichiometry. Since there is no oxygen excess, titanium reduction should primarily be compensated through eqn (1), i.e. the formation of oxygen vacancies and the $\mathrm{pO}_{2}{ }^{-1 / 4}$ dependence of conductivity should therefore be absent. Slater et al. ${ }^{26}$ indeed describe a $\mathrm{pO}_{2}^{-1 / 6}$ conductivity behaviour for A-site deficient La substituted $\mathrm{SrTiO}_{3}$. Plateau regions have been reported for A-site deficient $\mathrm{Nb}$ modified $\mathrm{SrTiO}_{3}$, but this could be due to slow reduction kinetics in dense samples. ${ }^{28}$

One of the drawbacks of using A-site deficient strontium titanates is the large driving force for phase segregation of $\mathrm{TiO}_{2}$ under reducing conditions. ${ }^{29}$ Although this behaviour seems mainly driven by non-stoichiometry, several authors observed segregation during sintering and cooling of cationstoichiometric compounds as well. ${ }^{30-32}$ This may be ascribed to formation of space-charge potentials in individual grains as function of differences in individual defect formation energies. ${ }^{33}$ Whereas extrinsic acceptor dopants tend to segregate at grain boundaries already under oxidising conditions, donor dopants have recently also been found to show this behaviour when sintered under reducing atmospheres. ${ }^{33,34}$ Results particularly suggest formation of a double space-charge layer, which 
results in an increased $\mathrm{B} / \mathrm{A}$-cation ratio $\pm 10 \mathrm{~nm}$ around the grain boundaries.

It is furthermore found by several people, that A-site deficient donor substituted titanates have superior sintering characteristics and thus mechanical strength over their cationstoichiometric counterparts. ${ }^{35,36}$ This is most likely due to the formation of SrO rich phases in cation-stoichiometric titanates, hindering grain growth. Instabilities on reduction-oxidation (redox) cycles have also been found for cation-stoichiometric titanates, which can also be related to the formation/ dissolution of these secondary phases.

As the cation mobility is very low in strontium titanates ${ }^{27,37}$ structural and compositional changes in the bulk phases during short-term repeated oxidation-reduction cycles are expected to be negligible. In contrast, grain boundary phases seem much more sensitive to variations of the $\mathrm{pO}_{2}$, as their conductivity seems closely related to the more mobile oxygen vacancies, and accumulated B-site acceptors. Hence, to some extent, it may only be possible to form the desired bulk structure at high temperature during sintering, and then regard it as "frozen". From a processing point of view, the Sr-deficiency is desirable as it improves mechanical properties of the material by reducing the formation of "SrO" phases. ${ }^{35}$ This should also help avoiding formation of insulating $\mathrm{SrZrO}_{3}$ phases. However, A-site deficiency does lead to increased possibility of $\mathrm{TiO}_{2}$ segregation into grain boundaries during sintering, especially under reducing atmospheres as stated earlier. Moreover, Burnat et al. recently published a report clearly showing Ti diffusion into common zirconia based electrolyte, when A-site deficient La substituted strontium titanates are used. ${ }^{38}$ Here diffusion seems much more pronounced in samples fired in air however, whereas firing under reducing conditions seems an effective way to limit this diffusion phenomenon. Similar behaviour was found for heavily A-site deficient Y-substituted $\mathrm{SrTiO}_{3}{ }^{39}$

The focus in the following sections is on three materials which are all donor substituted A-site deficient perovskites, i.e. $\mathrm{La}, \mathrm{Y}$ and $\mathrm{Nb}$ modified $\mathrm{SrTiO}_{3}$. Despite the fact that $\mathrm{La}$ and $\mathrm{Y}$ substitute on the perovskite A-site, whilst Nb modifies the Bsite, their defect chemistry should be equivalent. Some comparisons will however be drawn with compositions that are cation stoichiometric to illustrate the effect of different defect chemistry on especially electrical properties and redox stability.

\section{Electrical properties of modified strontium titanates}

As reported by several authors, ${ }^{19,40,41}$ the conductivity of strontium titanate based materials strongly depends on the thermal history of the sample. Studies on the defect chemistry of substituted $\mathrm{SrTiO}_{3}$ (with $\mathrm{La}, \mathrm{Nb}$ or Y as typical substituent) demonstrate that the charge compensation mode strongly depends on the oxygen partial pressure. The effects of changing oxygen partial pressure upon unmodified and differently modified strontium titanates are shown in Fig. 2, in which we can observe the p-type behaviour of the unmodified sample and the extended p-type behaviour of the acceptor modified sample at higher $\mathrm{pO}_{2}$, as well as the very high n-type conductivity of the A-site deficient sample at lower $\mathrm{pO}_{2}$ values. ${ }^{16,26}$

Since the thermal and atmospheric history of (modified) $\mathrm{SrTiO}_{3}$ samples has such a large influence on the measured materials properties and in particular the electrical properties, attention to sample preparation is critical. The importance of firing conditions is often overlooked in literature. For A-site deficient LST, YST and STN sintered in air, changes in electrical conductivity as function of the oxygen partial pressure have been observed to occur only very slowly at temperatures below approximately $1000{ }^{\circ} \mathrm{C} ;^{17,28,42,43}$ this has been ascribed to the afore mentioned slow cation diffusion in the crystal lattice. In spite of somewhat contrasting reports in the literature on this matter, it may therefore be expected that once an electrical conductivity has been established through pre-reduction of dense air sintered samples, this conductivity will stay virtually unchanged with redox cycling at temperatures below $1000{ }^{\circ} \mathrm{C} .{ }^{44}$ The behaviour of porous samples may however differ from this, as diffusion lengths in the bulk will be smaller and changes in the bulk conductivity might be observed with changing $\mathrm{pO}_{2}$. In situ reduction is certainly desirable from a processing point of view, as it eliminates a potentially expensive preparation step. In this review, we therefore present results on both pre-reduced samples as well as samples reduced in situ at SOFC temperatures, along with their redox behaviour. Also both dense and porous samples will be discussed, the latter being more relevant for SOFC anode applications.

\section{Electrical properties of pre-reduced donor-modified $\mathrm{SrTiO}_{3}$}

Firstly, to show the effect of reductive sintering, the electrical properties of Y substituted $\mathrm{SrTiO}_{3}$ (YST) will be discussed. The samples discussed have been sintered under reducing conditions $\left(4 \% \mathrm{H}_{2} / 96 \%\right.$ argon, at $\left.1400{ }^{\circ} \mathrm{C}\right)$ in order to try and 'freeze' in the metallic bulk properties..$^{39,45,46}$ Subsequently, the electrical properties of pre-reduced $\mathrm{Nb}$ and La substituted $\mathrm{SrTiO}_{3}$ will be presented, including the effect of redox cycling.

Y substituted $\mathrm{SrTiO}_{3}$. Fig. 3 shows the impact of composition (and hence defect chemistry) on the electrical conductivity of a series of YST materials. The substitution level of yttrium was set to be $7 \mathrm{~atm} \%$, as the limitation of yttrium solubility is about 8 atm $\%,{ }^{26}$ whereas the strontium amount was changed from 87 to $99 \mathrm{~atm} \%$. In the series, $\mathrm{Sr}_{87}-\mathrm{Sr}_{91}$ are A-site deficient samples, $\mathrm{Sr}_{93}$ is a cation-stoichiometric sample, and $\mathrm{Sr}_{95}-\mathrm{Sr}_{99}$ are B-site deficient samples. For all A-site deficient samples, the conductivities are around $100 \mathrm{~S} \mathrm{~cm}^{-1}$ at $800{ }^{\circ} \mathrm{C}$ and exhibit metallictype behaviour. In contrast, the B-site deficient samples show very low conductivities (down to $0.01 \mathrm{~S} \mathrm{~cm}^{-1}$ at $800{ }^{\circ} \mathrm{C}$ ), and exhibit semiconducting behaviour. The conductivity of the cation-stoichiometric sample $\left(\mathrm{Sr}_{93}\right)$ lies in-between.

According to Mott's theory, ${ }^{47}$ if the concentration of electrons in the conduction band - which means the concentration of $\mathrm{Ti}^{3+}$ in the present materials - exceeds a critical value, a transition from semiconducting to metal-like behaviour may take place. Asite deficient samples are expected to have a higher number of charge carriers $\left(\mathrm{Ti}^{3+}\right)$ through eqn (1) and (6). On the atomic scale, A-site deficiency will weaken the bond strength of the 


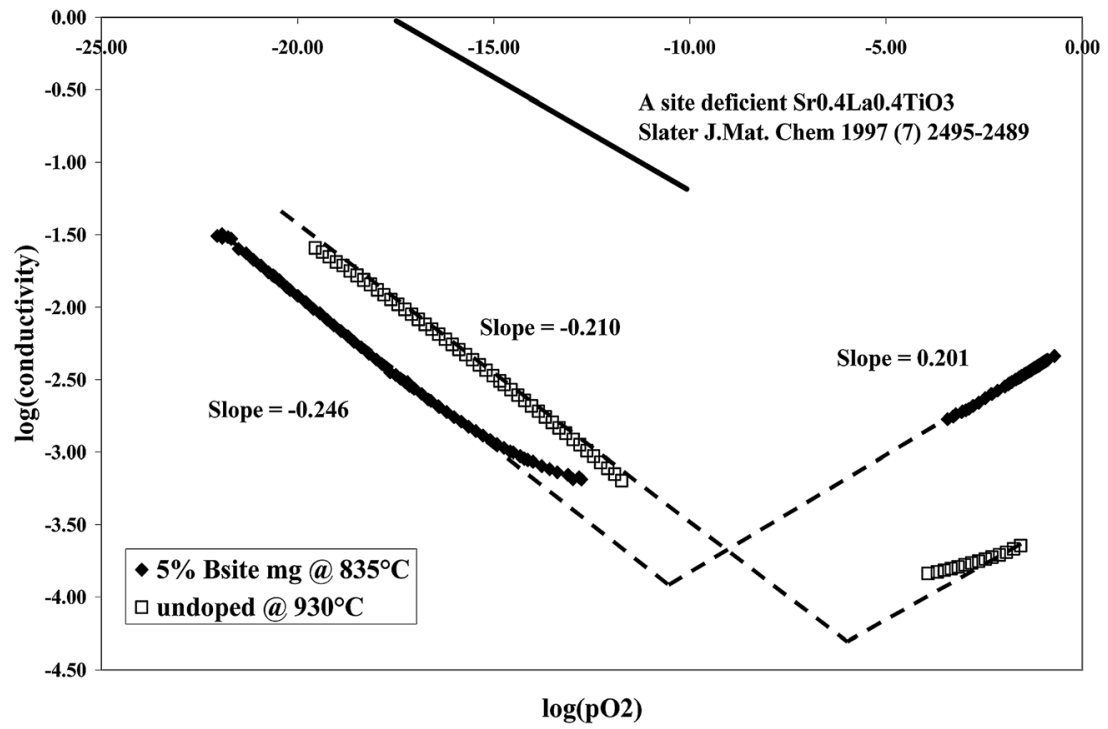

Fig. 2 Conductivity variation for $\mathrm{SrTiO}_{3}$ in different substitution scenarios. Solid line: A-site deficient donor substituted; squares: unmodified; diamonds: acceptor substituted. ${ }^{16,17}$ With kind permission from Springer Science and Business Media (original caption: SrTiO 3 and $\mathrm{SrTi}_{0.95} \mathrm{Mg}_{0.05} \mathrm{O}_{2.95}$ : conductivity variation with oxygen partial pressure at $930{ }^{\circ} \mathrm{C}$ ).

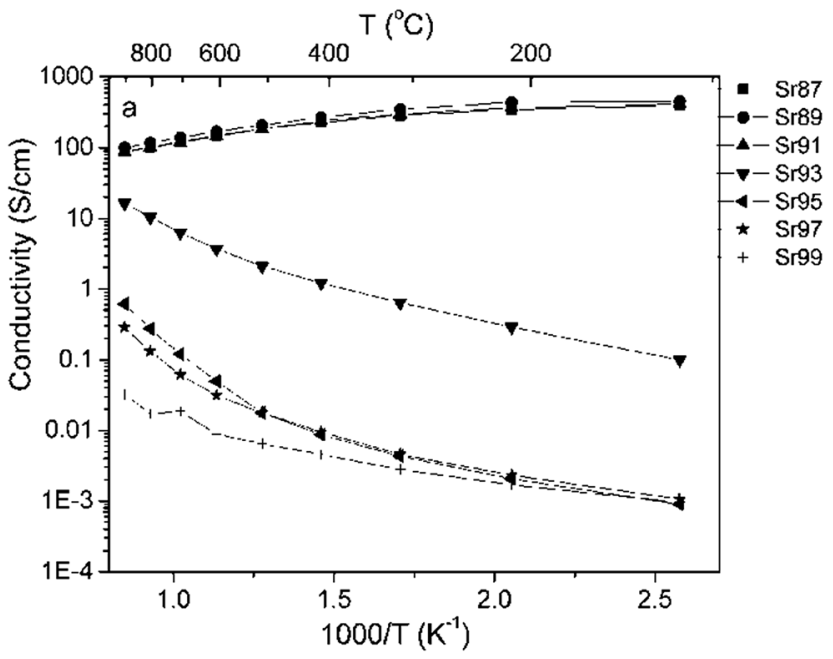

Fig. 3 Temperature dependence of the electrical conductivity in Ar/ $4 \% \mathrm{H}_{2} / 3 \% \mathrm{H}_{2} \mathrm{O}$ for samples with the general formula $\mathrm{Sr}_{1-x} \mathrm{Y}_{0.07} \mathrm{TiO}_{3-\delta}$ ranging from $x=0.13$ to $x=0.01$ ( $\mathrm{Sr}_{87}$ to $\mathrm{Sr}_{99}$ ) sintered in $\mathrm{Ar} / 4 \% \mathrm{H}_{2}$ at $1400{ }^{\circ} \mathrm{C}$ for $5 \mathrm{~h}$. Reprinted from Q. L. Ma, F. Tietz and D. Stover, Nonstoichiometric $\mathrm{Y}$-substituted $\mathrm{SrTiO}_{3}$ materials as anodes for solid oxide fuel cells, Solid State Ionics, 2011, 192, 535-539, with permission from Elsevier. ${ }^{46}$

adjacent $\mathrm{TiO}_{6}$ octahedra, which facilitates the reduction of $\mathrm{Ti}^{40}$ This may well be the main reason for the low conductivity and semiconducting behaviours of B-site deficient samples. And quite clearly, A-site deficient samples can reach the conductivity requirement for anode supports in SOFC.

In order to compensate for the low ionic conductivity of YST materials, YSZ can be added to form a composite, similarly to what is routinely done on Ni/YSZ cermets. However, Ti has been found in the YSZ electrolyte after co-sintering with an anode substrate made of $\mathrm{Sr}_{0.89} \mathrm{Y}_{0.07} \mathrm{Ti}_{x} \mathrm{O}_{3-\delta}$ (YST). ${ }^{39,45}$ It is known that Ti additions to YSZ increase unwanted electronic conduction in the electrolyte, ${ }^{\mathbf{4 8 , 4 9}}$ which will be discussed in next paragraphs. And moreover, the electrical properties of YST in the YST-YSZ anode functional layer are also different from those of pure YST. Because of the Ti diffusion into the electrolyte, the stoichiometry of YST in YST-YSZ may change from A-site deficiency to Bsite deficiency, which will result in a decrease of conductivity, as previously mentioned. Based on this assumption, YST samples with additional $\mathrm{TiO}_{2}$ were also prepared. Fig. 4 shows the

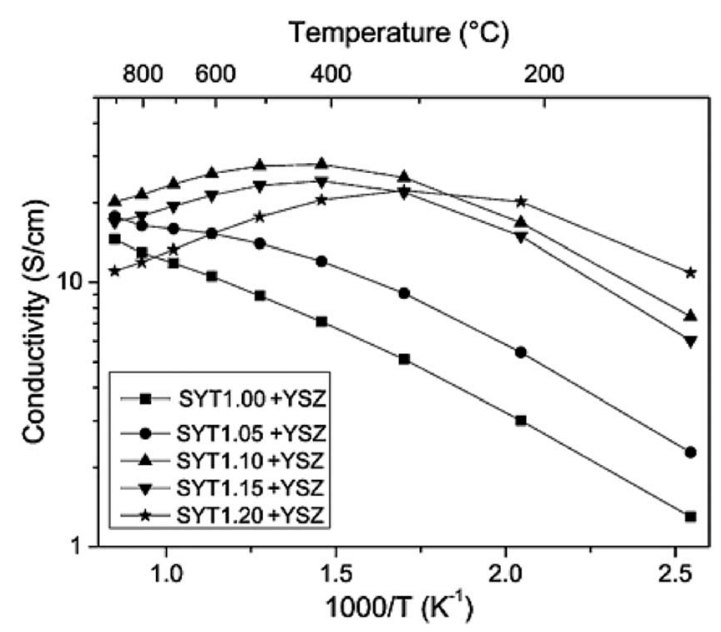

Fig. 4 Electrical conductivity in $\mathrm{Ar} / 4 \% \mathrm{H}_{2} / 3 \% \mathrm{H}_{2} \mathrm{O}$ of samples with the general formula $\mathrm{Sr}_{0.89} \mathrm{Y}_{0.07} \mathrm{Ti}_{x} \mathrm{O}_{3-\delta}$ with $1.0<x<1.2$, and mixed with YSZ in volume ratio $2: 1$. Reprinted from Q. Ma, F. Tietz, D. Sebold and D. Stover, $\mathrm{Y}$-substituted $\mathrm{SrTiO}_{3}-\mathrm{YSZ}$ composites as anode materials for solid oxide fuel cells: Interaction between YST and YSZ, Journal of Power Sources, 2010, 195, 1920-1925, with permission from Elsevier. ${ }^{39}$ 
conductivity of $\mathrm{Sr}_{0.89} \mathrm{Y}_{0.07} \mathrm{Ti}_{x} \mathrm{O}_{3-\delta} / \mathrm{YSZ}$ mixtures (2:1 in volume ratio, $\left.\mathrm{YST}_{x}-\mathrm{YSZ}, x=1.00-1.20\right)$ in humidified $\left(3 \% \mathrm{H}_{2} \mathrm{O}\right) 4 \%$ $\mathrm{H}_{2} / 96 \%$ argon atmospheres. As can be seen, the conductivity increases with increasing $x$ value in $\mathrm{YST}_{x}-\mathrm{YSZ}$ up to $x=1.10$, and this composition was found suitable for an anode functional layer for YST-based SOFC.

$\mathrm{Nb}$ substituted $\mathrm{SrTiO}_{3}$. Electrical testing of dense bulk specimens of STN94 $\left(\mathrm{Sr}_{0.94} \mathrm{Ti}_{0.9} \mathrm{Nb}_{0.1} \mathrm{O}_{3}\right)$ sintered under reducing conditions $\left(1400{ }^{\circ} \mathrm{C}, 12 \mathrm{~h}, 9 \% \mathrm{H}_{2} / 91 \% \mathrm{Ar}\right)$ shows relative independence of the conductivity with $\mathrm{pO}_{2}$, as shown in Fig. 5 . Although it may seem that it agrees well with the model of the electrical conductivity for cation-stoichiometric $\mathrm{Nb}$ substituted $\mathrm{SrTiO}_{3},{ }^{44}$ it really confirms the slow redox kinetics inside the grains in donor-modified $\mathrm{SrTiO}_{3}$. This may relate to low oxygen mobility in this particular composition, causing eqn (1) to occur very slowly. The sample in Fig. 5 was allowed to equilibrate for $\sim 30 \mathrm{~h}$ prior to each measurement.

First measurements on pre-reduced porous electrode backbones were mainly conducted at $1000{ }^{\circ} \mathrm{C}$, and at oxygen partial pressures in the range of $0.21-10^{-18}$ atm at this temperature. The backbones were applied onto pre-sintered YSZ, sintered at $1250{ }^{\circ} \mathrm{C}$ in air and afterwards re-reduced at $1250{ }^{\circ} \mathrm{C}$ for 3 hours in $9 \% \mathrm{H}_{2} / 91 \%$ argon. During testing, samples were kept at each $\mathrm{pO}_{2}$-step for $>30 \mathrm{~h}$ in order to allow the sample to equilibrate. The measurements started in the most reducing environment (wet $\mathrm{H}_{2}, \mathrm{pO}_{2} \approx 10^{-18} \mathrm{~atm}$ ). The $\mathrm{pO}_{2}$ was then increased stepwise up to air, and then back to reducing environment. The results are shown in Fig. 6.

At low $\mathrm{pO}_{2}$, the conductivity values of the porous samples correlate fairly well with the conductivity measured on dense samples, though not being corrected for porosity. However, where conductivity of the dense samples seemed independent of $\mathrm{pO}_{2}$, conductivity of porous samples show a slope close to $-1 / 6$ as expected for A-site deficiency, as shown by the lines in Fig. 6. Although only indicative, conductivity does not seem to fully recover on re-reduction of the samples, as also observed previously by Kolodiazhnyi and Petric. ${ }^{19}$ This hypothesis is

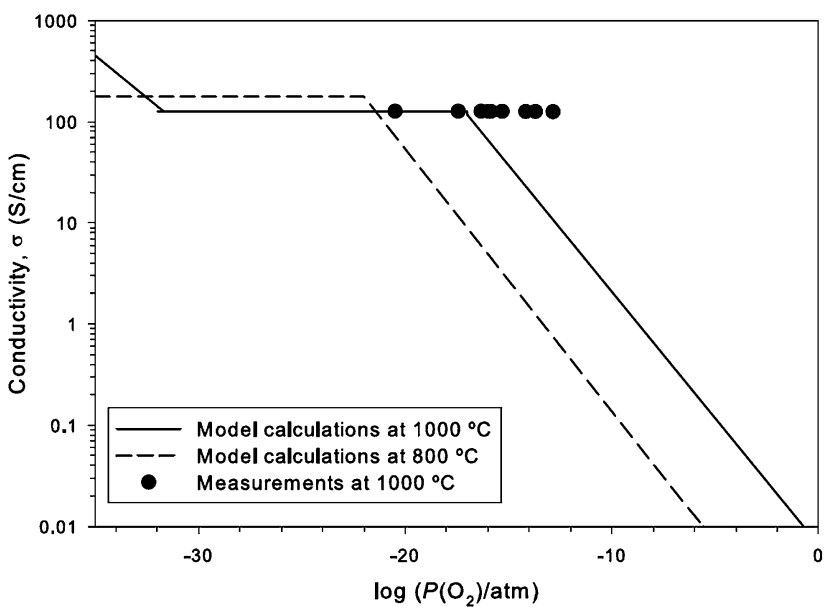

Fig. 5 Measured points of electrical conductivity for bulk STN94, overlaid with schematic graphs from modeling results. ${ }^{28}$

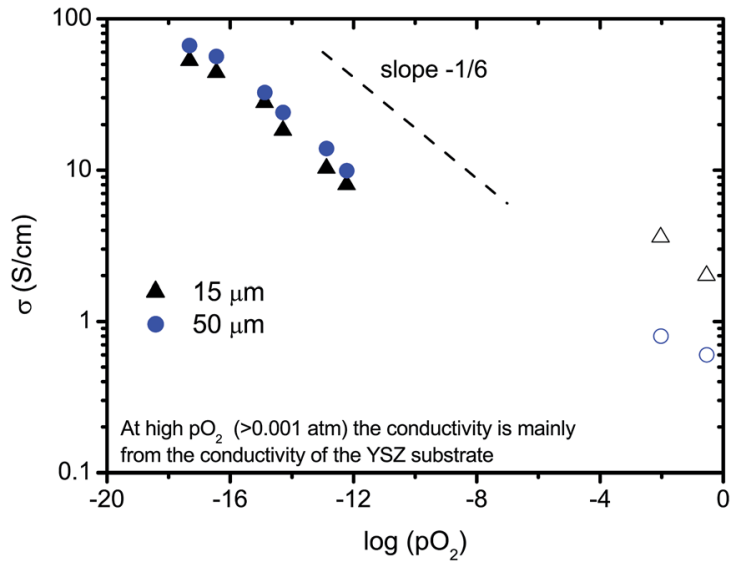

Fig. 6 Conductivity of printed STN94 electrodes with different layer thicknesses at $1000{ }^{\circ} \mathrm{C}$ and different $\mathrm{pO}_{2}$. Each data point was recorded after at least $30 \mathrm{~h}$ equilibration time at $1000^{\circ} \mathrm{C}$.

further supported by the conductivity measurements performed on porous STN94 samples that received different reduction profiles. One set of samples was pre-reduced at $1250{ }^{\circ} \mathrm{C}$ for $4 \mathrm{~h}$ in $9 \% \mathrm{H}_{2} / 91 \%$ argon, whereas another set was reduced in situ, during testing at $850{ }^{\circ} \mathrm{C}$. Conductivity started at $\sim 60 \mathrm{~S} \mathrm{~cm}^{-1}$ and $\sim 10 \mathrm{~S} \mathrm{~cm}^{-1}$ for the pre-reduced and the in situ reduced samples, respectively, and seems to respond with changing oxygen partial pressure fairly uniformly among the two tested sets. None of the samples regain the initial conductivity on re-reduction, with the pre-reduced material suffering the largest degree of degradation, as both sets ended up at $6-8 \mathrm{~S} \mathrm{~cm}^{-1}$ when brought again to low $\mathrm{pO}_{2}$ from atmospheric conditions. Inspection by SEM did not reveal any post-test changes of the STN94 microstructures.

The effect of defect chemistry on redox properties is shown by a direct comparison between STN94 $\left(\mathrm{Sr}_{0.94} \mathrm{Ti}_{0.9} \mathrm{Nb}_{0.1} \mathrm{O}_{3}\right)$ and STN99 $\left(\mathrm{Sr}_{0.99} \mathrm{Ti}_{0.9} \mathrm{Nb}_{0.1} \mathrm{O}_{3}\right)$, the latter of which has a much decreased A-site deficiency. STN99 samples, sintered under reducing atmosphere, showed an even stronger dependence on the environmental and thermal history, as may be deduced from conductivity results in Fig. 7, where STN99 powders were calcined in air $\left(1300{ }^{\circ} \mathrm{C} / 4 \mathrm{~h}\right)$ and sintered in $9 \% \mathrm{H}_{2} / 91 \%$ argon $\left(1450{ }^{\circ} \mathrm{C} / 10 \mathrm{~h}\right)$ under identical conditions, but where one of the powders was reduced at $1300{ }^{\circ} \mathrm{C}(10 \mathrm{~h})$ prior to sintering. The STN94 powder was also sintered similarly, under reducing conditions. All samples were sintered to near full density. The fact that STN94 after sintering in reducing atmosphere reaches conductivity levels close to STN99 samples is interesting from a point of how fast equilibrium establishes in STN-materials on sintering, as different conductivity values might have been expected considering the powder stoichiometry.

Measuring DC-conductivity on sintered STN99 based halfcells shows a surprisingly low redox-stability, as conductivity drops almost two decades on redox-cycling from the initial value of $\sim 100 \mathrm{~S} \mathrm{~cm}^{-1}$ at $850{ }^{\circ} \mathrm{C}$. In line with all the pre-reduced STN compounds, the STN99 half-cell showed metallic conductivity, however with a lower transition temperature. The maximum conductivity at $850{ }^{\circ} \mathrm{C}$ in highly reducing conditions was about $100 \mathrm{~S} \mathrm{~cm}^{-1}$. This conductivity decreased drastically 


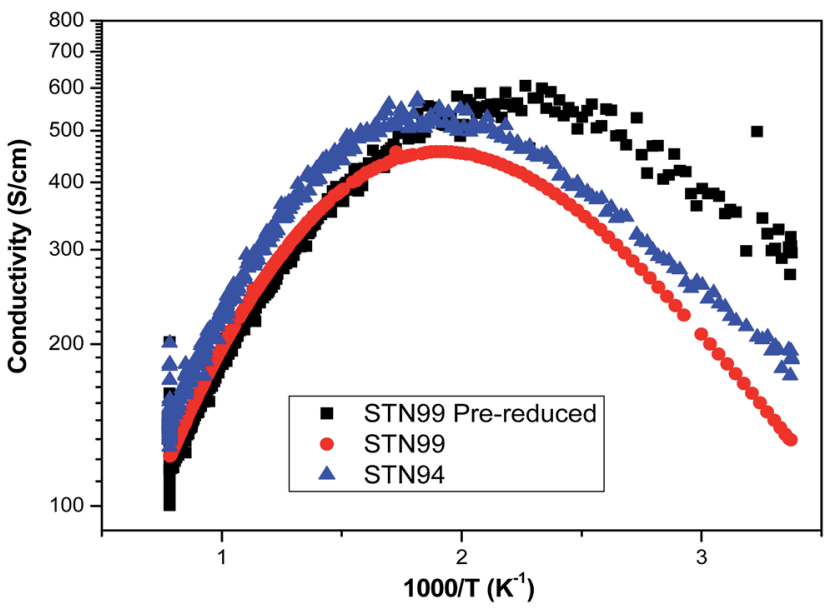

Fig. 7 DC conductivity behaviour of STN99 and STN94, all sintered to nearly full density at $1450{ }^{\circ} \mathrm{C}$ for $10 \mathrm{~h}$ in reducing atmosphere $(9 \%$ $\mathrm{H}_{2} / 91 \% \mathrm{Ar}$ ). "STN99 Pre-reduced" was furthermore calcined under reducing conditions.

with increasing $\mathrm{pO}_{2}$ reaching less than $0.01 \mathrm{~S} \mathrm{~cm}^{-1}$ at $\mathrm{pO}_{2}=$ $10^{-5}$ atm. Upon a new decrease in the $\mathrm{pO}_{2}$, regaining of conductivity was rather slow, and the maximum obtained at $10^{-24} \mathrm{~atm}$ was $\sim 2.5 \mathrm{~S} \mathrm{~cm}^{-1}$. After the test, the cell was partly cracked, but conductivity readings did not show discontinuity, and the cracking may not completely destroy the mechanical integrity of the sample. Due to the near cation-stoichiometry in STN99, cracking may have resulted from the formation of secondary SrO phases on oxidation, such as Ruddlesden Popper phases incorporated into the perovskite structure, and subsequent segregation of $\mathrm{Nb}$ and Ti-oxide on on reduction. ${ }^{19}$

The conductivity as a function of $\mathrm{pO}_{2}$ was also measured for a STN99 porous single layer, sintered at $1300{ }^{\circ} \mathrm{C}$ for $4 \mathrm{~h}$ in $9 \%$ $\mathrm{H}_{2} / 91 \%$ argon at $850{ }^{\circ} \mathrm{C}$, and a value of $140 \mathrm{~S} \mathrm{~cm}^{-1}$ was obtained at $10^{-20} \mathrm{~atm}$. The $\mathrm{pO}_{2}$ was then cycled between $10^{-19}$ atm and $10^{-12} \mathrm{~atm}$, where the conductivity reverted almost to its initial level. However, after subjecting the sample to a $\mathrm{pO}_{2}$ value of $\sim 10^{-5} \mathrm{~atm}$, the STN99 layer was unable to regain the original conductivity initially exhibited at $10^{-20}$ atm. Internal cracking was also seen for this sample.

La substituted $\mathrm{SrTiO}_{3}$. Pre-reduced $\mathrm{LST}_{\mathrm{A}-}\left(1050-1100{ }^{\circ} \mathrm{C}\right.$, $\left.\mathrm{pO}_{2} \sim 10^{-19} \mathrm{~atm}\right)$ is reported to have good conductivity, with $\mathrm{La}_{0.2} \mathrm{Sr}_{0.7} \mathrm{TiO}_{3}$ exhibiting values of $20-25 \mathrm{~S} \mathrm{~cm}^{-1}$ at $900{ }^{\circ} \mathrm{C}$ in $5 \%$ $\mathrm{H}_{2} / 95 \%$ argon. ${ }^{17}$ Similar values are obtained when increasing the A-site deficiency to $20 \%$, i.e. $\mathrm{La}_{0.4} \mathrm{Sr}_{0.4} \mathrm{TiO}_{3}{ }^{36}$ For this composition, Neagu showed that increasing the pre-reduction temperature from $1100{ }^{\circ} \mathrm{C}$ to $1400{ }^{\circ} \mathrm{C}$, causes an increase in conductivity from $20 \mathrm{~S} \mathrm{~cm}^{-1}$ to $\sim 100 \mathrm{~S} \mathrm{~cm}^{-1}$ at $880{ }^{\circ} \mathrm{C}$ and $\mathrm{pO}_{2}=10^{-20}$. Redox cycling of pre-reduced samples at $900{ }^{\circ} \mathrm{C}$ seems to impose a permanent loss of their conductivity by $\sim 50 \%$. Small improvements in the electrical properties of this composition were obtained when substituting $\mathrm{Sr}$ with $\mathrm{Ca}^{.0}{ }^{50} \mathrm{This}$ improvement is believed to be due to a decrease in the unit cell parameters, which enhances $\mathrm{Ti}$ orbital overlap and thus conductivity. A change to lower symmetry at higher $x$ leads to tilting of the $\mathrm{TiO}_{6}$ octahedra, in turn causing deterioration in the orbital overlap. Fig. 8 shows the conductivity for dense samples with varying $x$ at $900{ }^{\circ} \mathrm{C}$ and $\mathrm{pO}_{2}=10^{-19}$ atm. A maximum in the conductivity of $28 \mathrm{~S} \mathrm{~cm}^{-1}\left(900^{\circ} \mathrm{C}^{\mathrm{pO}_{2}} \sim 10^{-19}\right.$ atm) was obtained for $x=0.45$ in $\mathrm{La}_{0.2} \mathrm{Sr}_{1-x} \mathrm{Ca}_{x} \mathrm{TiO}_{3}$.

During SOFC operation it should be expected that redox cycles to near atmospheric conditions occur on several occasions during a system's lifespan. The above results show that pre-reduction of donor-modified $\mathrm{SrTiO}_{3}$ samples only guarantees superior conductivity values when the samples are kept within a narrow $\mathrm{pO}_{2}$ range, i.e. $\sim 10^{-20}$ to $10^{-10}$ atm. These conductivity values cannot be recovered when the samples have been exposed to air $\left(\mathrm{pO}_{2}=0.2 \mathrm{~atm}\right)$.

\section{Electrical properties of in situ reduced donor-modified $\mathrm{SrTiO}_{3}$}

In this section, a brief overview will be given for the properties of materials which have been reduced in situ. Because of the limited reduction kinetics of modified strontium titanates at SOFC operating conditions $\left(800-900{ }^{\circ} \mathrm{C}\right)$, few papers actually report conductivity values obtained in this way. Some examples of A-site deficient La substituted $\mathrm{SrTiO}_{3}$ will be discussed and a brief comparison with pre-reduced conductivity values will also be given to show the effect of thermal history, which may help understand the large range of reported conductivities and apparent discrepancies found in literature.

The conductivity of dense in situ reduced $\mathrm{La}_{x} \mathrm{Sr}_{1-3 x / 2} \mathrm{TiO}_{3}$ samples, where $x=0.2-0.6$, was studied in detail by Slater et al. ${ }^{26}$ Highest conductivities of $7 \mathrm{~S} \mathrm{~cm}^{-1}$ were reported for $x=$ 0.6 at $930{ }^{\circ} \mathrm{C}$ and $\mathrm{pO}_{2}=10^{-20} \mathrm{~atm}$. after equilibrating for 24 hours. Similar values are reported by Neagu and Irvine ${ }^{36}$ on porous samples (62\% TD), with $x=0.4$. Despite the porosity, equilibration is still slow and takes more than 20 hours. Savaniu and Irvine report conductivity values of $\sim 3 \mathrm{~S} \mathrm{~cm}^{-1}$ for both dense and porous $\mathrm{La}_{0.2} \mathrm{Sr}_{0.7} \mathrm{TiO}_{3}$ samples, in identical atmosphere and after similar equilibration times. ${ }^{17}$ Prereduction of these samples at $1050-1100{ }^{\circ} \mathrm{C}$ (in $5 \% \mathrm{H}_{2} / 95 \%$ argon), increases their conductivity by nearly an order of magnitude, i.e. $20-25 \mathrm{~S} \mathrm{~cm}^{-1}$.

Both Slater and Savaniu report an approximate $\mathrm{pO}_{2}{ }^{-1 / 6}$ dependency of the conductivity at $\mathrm{pO}_{2}<10^{-15}$ atm, suggesting an oxygen vacancy compensated mechanism, according to eqn (1). This is to be expected in A-site deficient strontium titanates as explained in the defect chemistry section. The formation of oxygen vacancies might furthermore be beneficial for its application as SOFC anode material, as it may create some oxygen ion mobility, thus increasing the thickness of the active anode for fuel oxidation.

Neagu and Irvine also showed that substitution on the B-site with gallium $\left(\mathrm{La}_{0.4} \mathrm{Sr}_{0.4} \mathrm{Ti}_{1-x} \mathrm{Ga}_{x} \mathrm{O}_{3-x / 2}, x<0.15\right)$, improves both the conductivity in oxidising as well as reducing conditions. It is suggested that $\mathrm{Ga}$ enhances the reduction of $\mathrm{Ti}$, due to weakening of the BO bonds. This also leads to greatly improved reduction kinetics at any given temperature. However, some Ga loss was observed with time, due to the volatility in the form of $\mathrm{Ga}_{2} \mathrm{O}$ and $\mathrm{GaOH}$ species. Fig. 9 shows the variation of conductivity of $\mathrm{La}_{0.4} \mathrm{Sr}_{0.4} \mathrm{Ti}_{1-x} \mathrm{Ga}_{x} \mathrm{O}_{3-x / 2}$ with time at $880{ }^{\circ} \mathrm{C}$ and $\mathrm{pO}_{2}=$ $10^{-18}$ atm. 


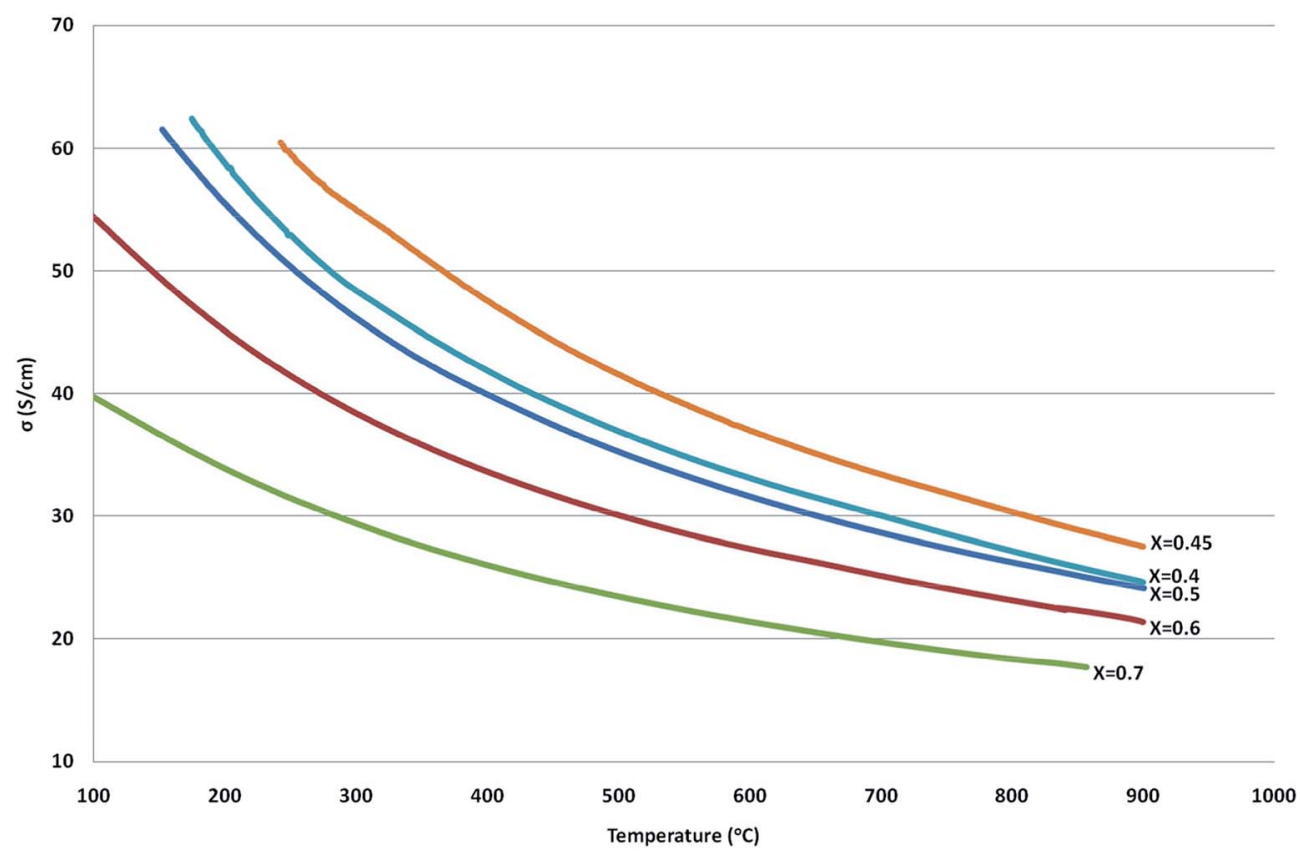

Fig. 8 Electrical conductivity for pre-reduced dense samples of $\mathrm{La}_{0.2} \mathrm{Sr}_{1-x} \mathrm{Ca}_{x} \mathrm{TiO}_{3}$ at $900{ }^{\circ} \mathrm{C}$ and $\mathrm{pO}_{2}=10^{-19}$ atm (reproduced from ref. 50).

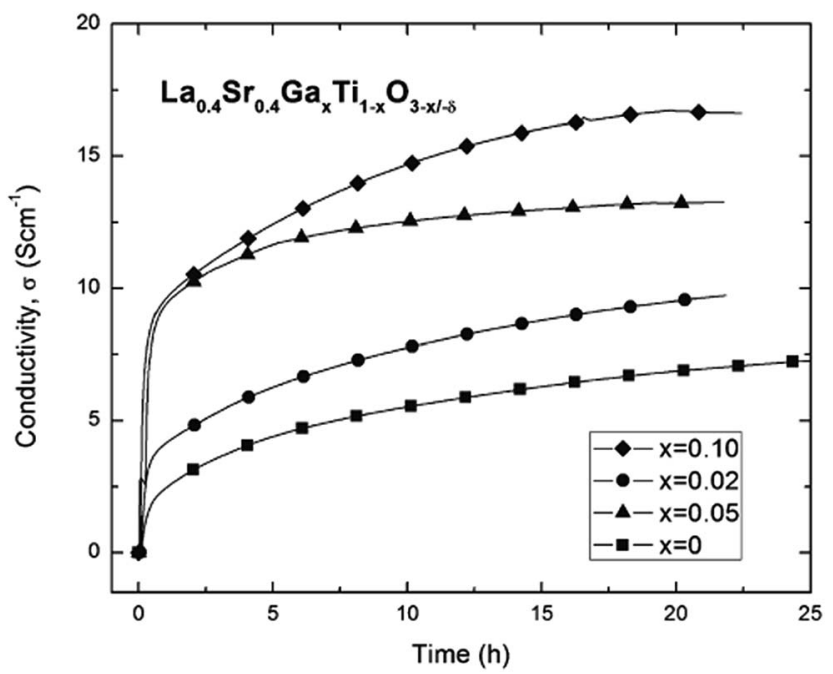

Fig. 9 Conductivity of in situ reduced $\mathrm{La}_{0.4} \mathrm{Sr}_{0.4} \mathrm{Ti}_{1-x} \mathrm{Ga}_{x} \mathrm{O}_{3-x / 2}$ at $880{ }^{\circ} \mathrm{C}$ and $\mathrm{pO}_{2}=10^{-18}$ atm..$^{51}$ Reprinted with permission from "D. Neagu and J. T. S. Irvine, Chemistry of Materials, 2011, 23, 1607-1617". Copyright 2011 American Chemical Society.

In situ reduction at $850{ }^{\circ} \mathrm{C}$ in $5 \% \mathrm{H}_{2} / 95 \%$ argon of porous $\mathrm{La}_{0.2} \mathrm{Sr}_{1-x} \mathrm{Ca}_{x} \mathrm{TiO}_{3}$ electrodes with $x=0.45$ has resulted in conductivity values in excess of $5 \mathrm{~S} \mathrm{~cm}^{-1} .^{52}$ As mentioned earlier, pre-reduction of dense samples at $1050{ }^{\circ} \mathrm{C}$ results in conductivity values of $28 \mathrm{~S} \mathrm{~cm}^{-1}$ at $900{ }^{\circ} \mathrm{C}$. Yaqub et al. performed redox cycles on in situ ( $880{ }^{\circ} \mathrm{C}, 5 \% \mathrm{H}_{2} / 95 \%$ argon) reduced porous bars with the same composition $\left(\mathrm{La}_{0.20} \mathrm{Sr}_{0.25} \mathrm{Ca}_{0.45} \mathrm{TiO}_{3}\right){ }_{.}^{53}$ The porosity and lack of pre-reduction results in a drop of conductivity of approximately an order of magnitude, but constant conductivity values are obtained on redox cycling between $\mathrm{pO}_{2}=10^{-17}$ to $0.21 \mathrm{~atm}$, with no sign of sample degradation or mechanical failure. The authors further noticed a marked increase in the redox kinetics, when impregnating the bars with ceria. Whilst un-impregnated bars required $\sim 3$ hours of reduction to attain reasonable conductivity values, upon ceria impregnation this time reduced by about $50 \%$.

\section{Fuel cell performance of A-site deficient $\mathrm{La}, \mathrm{Y}$ and $\mathrm{Nb}$ substituted $\mathrm{SrTiO}_{3}$}

This review is concluded with a short overview of the use of said titanate materials in SOFC anodes. Where available, the effect of A-site deficiency on important stability aspects, such as redox cycling and mechanical robustness, will be described.

\section{$\mathrm{LST}_{\mathrm{A}-\text { based anodes }}$}

A comprehensive review was recently written on the fuel cell performance of many La substituted $\mathrm{SrTiO}_{3}$ based anode materials by Zhou et al. ${ }^{54}$ Here we limit ourselves to the performance of some A-site deficient lanthanum substituted strontium titanates.

Savaniu and Irvine showed promising fuel cell results for both electrolyte and anode supported cell (ESC and ASC, respectively) designs comprising $\mathrm{La}_{0.2} \mathrm{Sr}_{0.7} \mathrm{TiO}_{3}\left(\mathrm{LST}_{\mathrm{A}-}\right)$ anodes. ${ }^{17}$ Using $\mathrm{LST}_{\mathrm{A}-}$ as the anode backbone impregnated with nanosized metal (oxide) catalysts $\left(\mathrm{CeO}_{2}\right.$ and $\mathrm{Cu}$ ), they achieved good performance using humidified hydrogen at temperatures as low as $600{ }^{\circ} \mathrm{C}$. Power densities in excess of $0.4 \mathrm{~W} \mathrm{~cm}{ }^{-2}$ were obtained at $750{ }^{\circ} \mathrm{C}$ in an anode supported cell configuration, as shown in Fig. 10. They noticed that for both cell designs, performance was limited by ohmic losses, originating from 


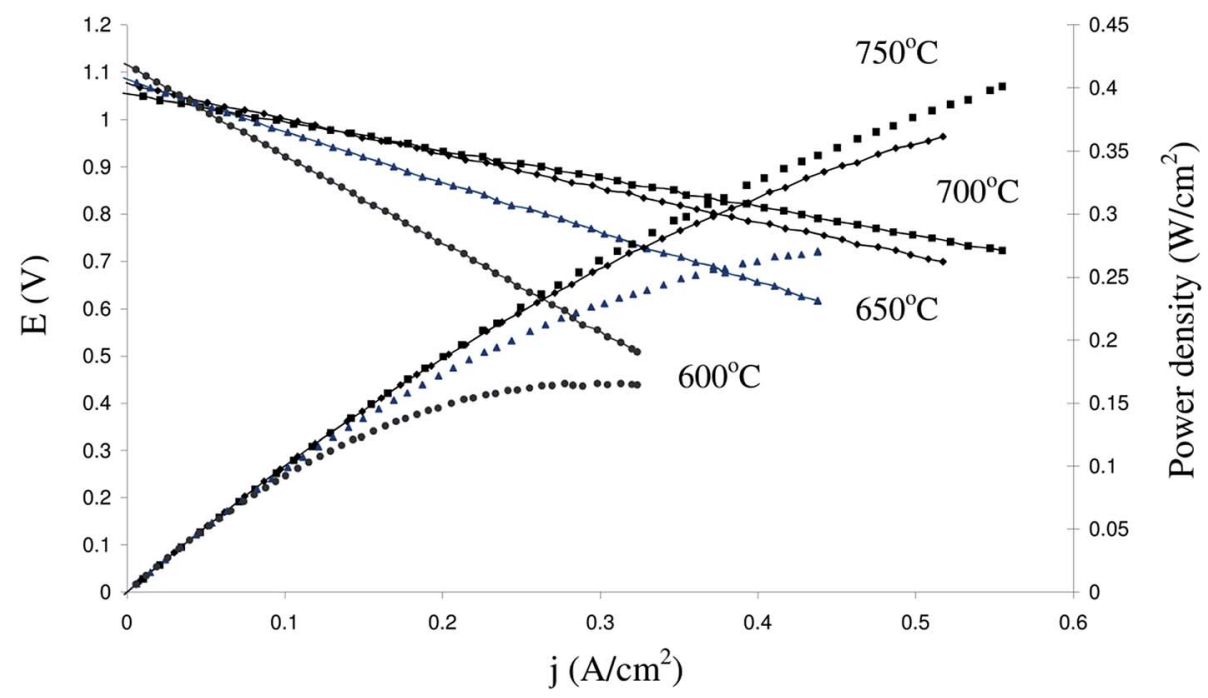

Fig. 10 Fuel cell performance of anode supported $\mathrm{LST}_{\text {A- }}$ cell at different temperatures in pure humidified $\mathrm{H}_{2}\left(2.3 \% \mathrm{H}_{2} \mathrm{O}\right)$ and pure $\mathrm{O}_{2}($ reproduced from ref. 17).

both the electrolyte as well as electrodes. Fig. 11 shows the impedance spectra for the anode supported cell at different temperatures. To achieve these performances at relatively low temperatures for SOFC, the anodes had been pre-reduced prior to the experiments. The anode performance is furthermore comparable to those of infiltrated YSZ scaffolds with an $\mathrm{LST}_{\mathrm{O}-}$ (cation-stoichiometric La substituted $\mathrm{SrTiO}_{3}$ ) current collecting layer $^{55}$ and to composite anodes in which (LST $\mathrm{O}_{\mathrm{O}}$ ) has been impregnated into a porous YSZ scaffold with further enhancement from infiltrated $\mathrm{CeO}_{2}$ and $\mathrm{Pd}^{56}$

Similarly promising results have been found using a $\mathrm{Ca}$ substituted A-site deficient $\mathrm{La}_{0.2} \mathrm{Sr}_{0.7} \mathrm{TiO}_{3}$ as anode backbone in an electrolyte supported cell, impregnated with a combination of ceria and nickel catalysts. A stable area specific resistance of $0.37 \Omega \mathrm{cm}^{2}$ was achieved after 20 redox cycles and 250 hours of operation at $900{ }^{\circ} \mathrm{C}$ in $\mathrm{H}_{2}$ with $8 \% \mathrm{H}_{2} \mathrm{O}$, showing excellent redox stability. Power densities in excess of $0.5 \mathrm{~W} \mathrm{~cm}^{-2}$ could be obtained for these cells. ${ }^{52}$ This shows the promise for this type of material as a potential conductive backbone, whilst modification by infiltration can provide the necessary electrocatalytic activity.

\section{YST $_{A^{-}}$based anodes}

Forschungzentrum Juelich has developed an anode supported cell based on $\mathrm{YST}_{\mathrm{A}}$, demonstrating the mechanical robustness of A-site deficient titanates. Fig. 12 shows the cross section of such a cell. ${ }^{57}$ The anode supports with electrolyte layer, undergo a final firing step under reducing conditions. ${ }^{58}$ About $3 \mathrm{wt} \% \mathrm{NiO}$

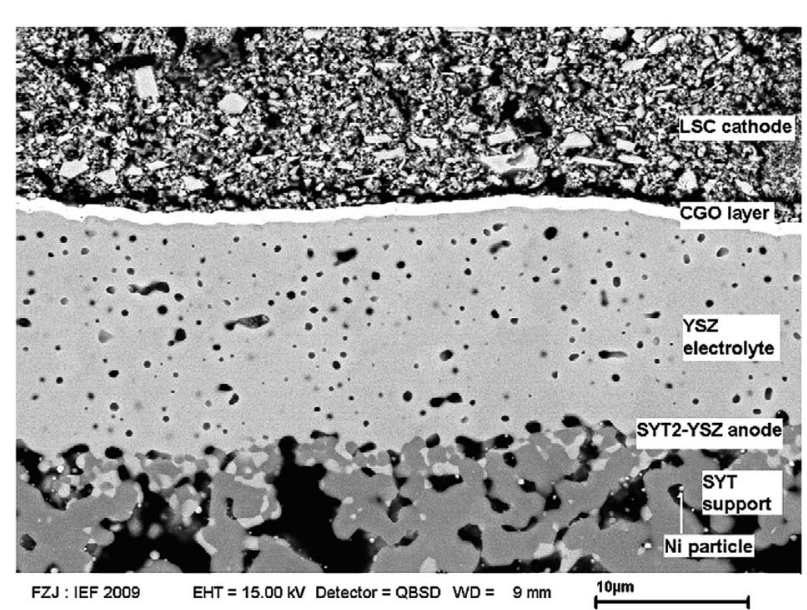

Fig. 12 Cross section of YST-ASC composed of YST/YST1.10-YSZ/ YSZ/PVD-CGO/LSC. Reprinted from Q. L. Ma, F. Tietz, A. Leonide and E. Ivers-Tiffee, Anode-supported planar SOFC with high performance and redox stability, Electrochemistry Communications, 2010, 12, 1326-1328, with permission from Elsevier. ${ }^{57}$

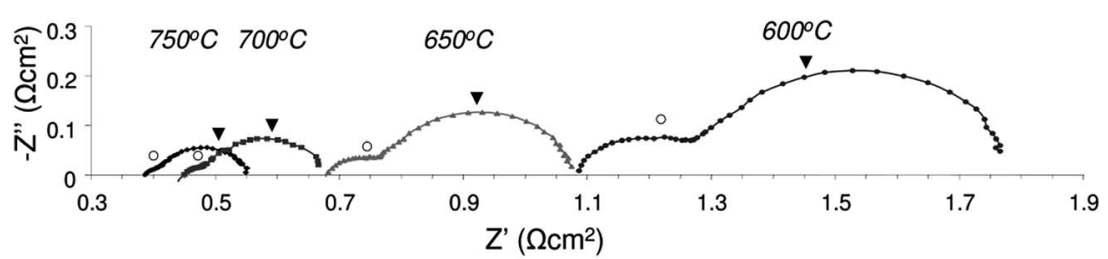

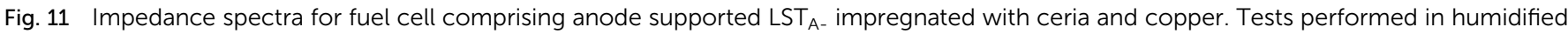
(2.3\% $\mathrm{H}_{2} \mathrm{O}$ ) pure $\mathrm{H}_{2}$ and pure $\mathrm{O}_{2}$ (reproduced from ref. 17). 
is subsequently impregnated into the anode structure to provide catalytic activity for the fuel oxidation reaction.

Analysis of the electrolyte by Energy Dispersive Spectroscopy confirms the likelihood of Ti diffusion from the $\mathrm{YST}_{\mathrm{A}^{-}}$into zirconia, although this may be exaggerated due to the addition of $10 \mathrm{wt} \% \mathrm{TiO}_{2}$ to the anode support. A gradient of the $\mathrm{Ti}$ content from 4.5 to 12.5 atm\% in the electrolyte layer was noticed, decreasing from the anode side to cathode side, suggesting possible electronic conduction in the co-sintered electrolyte.

The performance of the $\mathrm{YST}_{\mathrm{A}}$ - ASC was characterized electrochemically by means of current voltage $(I / U)$, and impedance measurements. Typical $I / U$ characteristics recorded at different temperatures is shown in Fig. 13 . At $800{ }^{\circ} \mathrm{C}$, a typical operation temperature for SOFC systems, an OCV of $1.09 \mathrm{~V}$ is obtained, very close to the theoretical value and indicating that the $\mathrm{Ti}$ content in the electrolyte layer, especially for the region close to cathode with only 4-5 at\% of $\mathrm{Ti}$, does not cause significant electronic conduction. At the same temperature, a current density of $1.22 \mathrm{~A} \mathrm{~cm}^{-2}$ at $0.7 \mathrm{~V}$ is achieved, which corresponds to a power density of $0.85 \mathrm{~W} \mathrm{~cm}^{-2}$. The actual data for all the tested cells so far varied from 1.0 to $1.5 \mathrm{~A} \mathrm{~cm}^{-2}$ at $0.7 \mathrm{~V}$ and $800{ }^{\circ} \mathrm{C}$. Although compared with the state-of-the-art cells the performance of YST-based cells is still lower (see Table 1), it has already reached the level of practical use and has a valid prospect for commercial application.

Fig. 14 shows the changes of OCV and performance at $0.7 \mathrm{~V}$, of the cell as a function of the numbers of redox cycles. Impressively, after 200 redox cycles, the OCV only decreased by $1.3 \%$, indicating the high robustness and stability of the cell. In contrast, state-of-the-art SOFCs based on Ni cermets usually collapsed, or had apparent losses of OCV after just one redox cycle. ${ }^{9}$ However, the performance of the cell decreased by $35 \%$

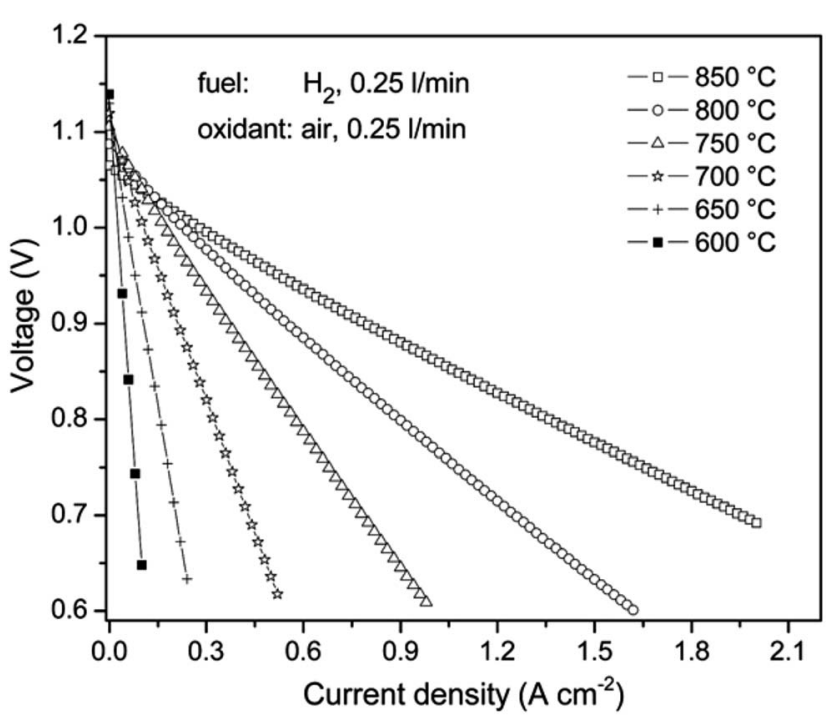

Fig. 13 Current-voltage curves of an YST ASC for temperatures ranging from 600 to $850{ }^{\circ} \mathrm{C}$. Reprinted from Q. L. Ma, F. Tietz, A. Leonide and E. Ivers-Tiffee, Anode-supported planar SOFC with high performance and redox stability, Electrochemistry Communications, 2010, 12, 1326-1328, with permission from Elsevier. ${ }^{57}$
Table 1 Power densities (at voltage output of $0.7 \mathrm{~V}$, in $\mathrm{mW} \mathrm{cm}^{-2}$ ) vs. temperature of the reported $\mathrm{YST}^{-\mathrm{ASC}^{57}}$ and a state-of-the-art anode supported cells ${ }^{59}$

\begin{tabular}{lcc}
\hline Temperature & YST-ASC & SoA-ASC \\
\hline $800{ }^{\circ} \mathrm{C}$ & 855 & 1314 \\
$750{ }^{\circ} \mathrm{C}$ & 551 & 931 \\
$700{ }^{\circ} \mathrm{C}$ & 294 & 600 \\
$650{ }^{\circ} \mathrm{C}$ & 145 & 356 \\
$600{ }^{\circ} \mathrm{C}$ & 62 & 193
\end{tabular}

after 200 redox cycles. The reason is most likely the gradual loss of electrical conductivity after each redox cycle either due to an irreversible decrease of charge carriers, or due to the slow kinetics between the reduced and oxidized state of YST materials. As previously mentioned, the conductivity of YST sintered in reducing atmosphere, as well as other $\mathrm{SrTiO}_{3}$ based materials, depends significantly on the oxygen partial pressure during testing. The values are nearly $100 \mathrm{~S} \mathrm{~cm}^{-1}$ after sintering at $1400{ }^{\circ} \mathrm{C}$ in $\mathrm{H}_{2}$ /argon, but only about $0.01 \mathrm{~S} \mathrm{~cm}^{-1}$ in air, both measured at $800^{\circ} \mathrm{C}$. If the atmosphere is changed from air back to argon $/ \mathrm{H}_{2}$, the conductivity can be restored to some extent, but this may take considerably longer than the cycles used in this study. It is very likely that the 10 minutes interval for reduction during the redox cycle is not long enough for recovery of the conductivity after the oxidizing period (also 10 minutes). Hence, this results in a continuous performance decrease with continued redox cycling. This may be further investigated by redox tests with longer periods of reduction. Fig. 14 also shows the change of performance of a different cell, at $0.7 \mathrm{~V}$ and 800 ${ }^{\circ} \mathrm{C}$, as a function of the numbers of redox cycles. For this test the reducing time during the cycles was prolonged to 2 hours, and

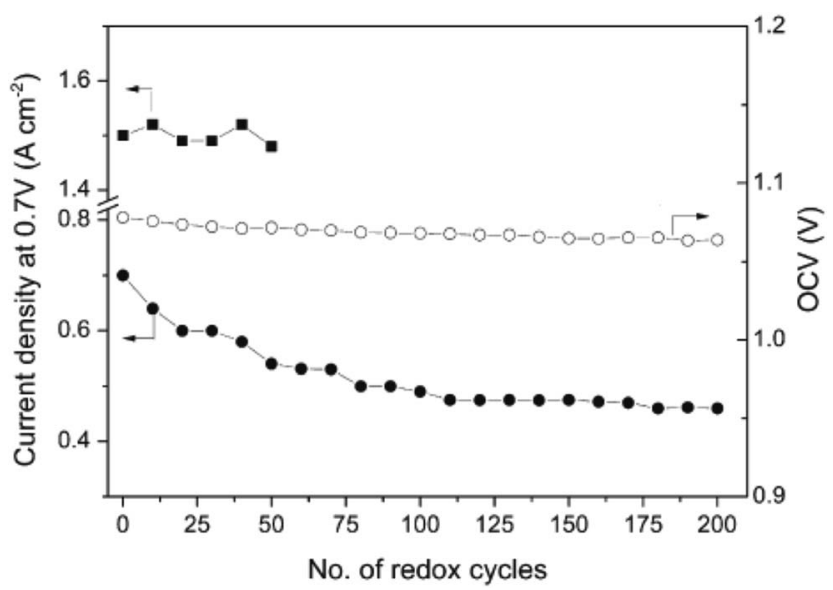

Fig. $14 \mathrm{OCV}$ (open circles) and current density at $0.7 \mathrm{~V}$ (closed circles) as a function of the number of redox cycles ( 10 minutes in $\mathrm{H}_{2}$ and 10 minutes in air) at $750{ }^{\circ} \mathrm{C}$ as well as current density at $0.7 \mathrm{~V}$ (closed squares) as a function of the number of redox cycles at $800{ }^{\circ} \mathrm{C}$ applying $2 \mathrm{~h}$ in $\mathrm{H}_{2}$ and 10 minutes in air. Reprinted from Q. L. Ma, F. Tietz, A. Leonide and E. Ivers-Tiffee, Anode-supported planar SOFC with high performance and redox stability, Electrochemistry Communications, 2010, 12, 1326-1328, with permission from Elsevier. ${ }^{57}$ 
the oxidizing period remained 10 minutes. As anticipated, there is no apparent decrease in performance after 50 redox cycles. More studies will be required however to establish whether any adverse changes in the electrical properties occur on longer oxidation periods. Nevertheless, performance values for cells based on YST anode are remarkably high, and among the best yet reported for cells with a ceramic anode (see Table 2).

\section{STN $_{\text {A- }}$ based anodes}

Fuel cell tests on $\mathrm{STN}_{\mathrm{A}-}$ based anodes have so far been limited and mainly involve symmetrical cell testing in single (wet) hydrogen atmospheres. A first generation of these symmetrical cells comprised STN94 (single phase or composite with YSZ, w/w $1: 1$ ) electrodes spray deposited onto 8-YSZ electrolyte substrates. After sintering in air at $1250{ }^{\circ} \mathrm{C}$, the anodes with thicknesses of 15-30 $\mu \mathrm{m}$ were infiltrated with $20-30 \mathrm{wt} \%$ $\mathrm{Ce}_{0.8} \mathrm{Gd}_{0.2} \mathrm{O}_{1.9}$ (CGO). The resulting crystallite size of the infiltrate was found to vary strongly with calcination temperature, namely $5 \mathrm{~nm}, 14 \mathrm{~nm}$ and $40 \mathrm{~nm}$ at $350{ }^{\circ} \mathrm{C}, 650{ }^{\circ} \mathrm{C}$ and $850{ }^{\circ} \mathrm{C}$, respectively. ${ }^{28,60}$ Promising results were obtained by measuring the cells' electrical impedance. Negligible series resistances were found when using Pt current collection and polarisation resistances were comparable with state-of-the-art Ni/YSZ anodes. The impedance spectra at various temperatures are shown in Fig. 15. In addition, the CGO infiltrated electrode was shown to be redox stable and even slightly activated by redox cycling at $650-850{ }^{\circ} \mathrm{C}$.

A combination of Ni and CGO was also infiltrated into STN94 electrodes. Here the nickel was applied on already deposited CGO. Symmetrical cell measurements at open circuit voltage (OCV) in a one-atmosphere set-up showed an electrochemical activity comparable to the current state-of-the-art Ni/YSZ fuel electrode in SOFC applications, i.e. $\sim 0.12 \Omega \mathrm{cm}^{2}$ at $850{ }^{\circ} \mathrm{C}$. Due to an apparently low activation energy of the electrode (around 0.5-0.7 eV), high performance was achieved at lower temperatures, where the best electrode, a Ni/CGO infiltrated electrode, showed a polarisation resistance of $0.22 \Omega \mathrm{cm}^{2}$, in $\mathrm{H}_{2}$ with $\sim 3 \%$ steam at $650{ }^{\circ} \mathrm{C}^{61} \mathrm{~A}$ micrograph of a CGO infiltrated STN94 electrode is shown in Fig. 16.

A Ni/CGO infiltrated electrode supported by a STN99 backbone sintered for 4 hours at $1320{ }^{\circ} \mathrm{C}$ in $9 \% \mathrm{H}_{2} / 91 \%$ argon was subjected to a single redox cycle of 91 hours to evaluate the

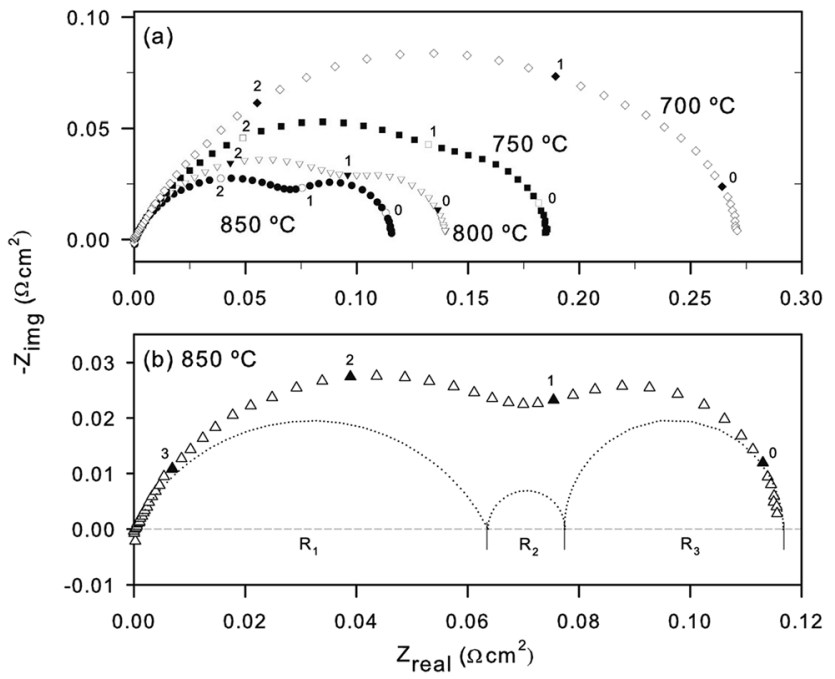

Fig. 15 Impedance spectra for STN94 infiltrated with CGO at various temperatures in humidified $\left(3 \% \mathrm{H}_{2} \mathrm{O}\right)$ hydrogen. Spectra have been corrected for $R_{\mathrm{s}}{ }^{60}$ (reproduced with permission from ECS Transactions, 2008, 13, 181-194. Copyright 2008, The Electrochemical Society).

electrode degradation behaviour at $800{ }^{\circ} \mathrm{C}$, under high steam concentration (85\%). Its series resistance, $R_{\mathrm{s}}$, increased by $37 \%$ and polarisation resistance, $R_{\mathrm{p}}$, by $36 \%$, which corresponds to degradation rates at $\sim 400 \%$ per $1000 \mathrm{~h}$ for these conditions. The electrodes were re-reduced after the exposure to steam and although the summit frequencies visualised through a Bode plot of impedance data returned to their original values and some recovery took place, neither $R_{\mathrm{S}}$ nor $R_{\mathrm{p}}$ returned to their original values, leaving a permanent degradation of $20 \%$ and $19 \%$ for $R_{\mathrm{s}}$ and $R_{\mathrm{p}}$ values, respectively. Longer exposure to reducing conditions may lead to more recovery, but it still indicates that the performance of the Ni/CGO electrode is sensitive to the steam concentration, which may be linked to the fact that protons associate with the oxygen sub-lattice in CGO.

$$
\mathrm{H}_{2} \mathrm{O}+\mathrm{V}_{\mathrm{O}}^{\ddot{*}}+\mathrm{O}_{\mathrm{O}}^{\times} \rightleftarrows 2 \mathrm{OH}_{\mathrm{O}}^{\cdot}
$$

The DC-conductivity measurements mentioned earlier showed that a $200 \mu \mathrm{m}$ thick STN99-backbone of similar size will

Table 2 Reported single cell test results based on redox-stable anode materials. All cells tests were performed with $\mathrm{H}_{2}$ as fuel and air as oxidant

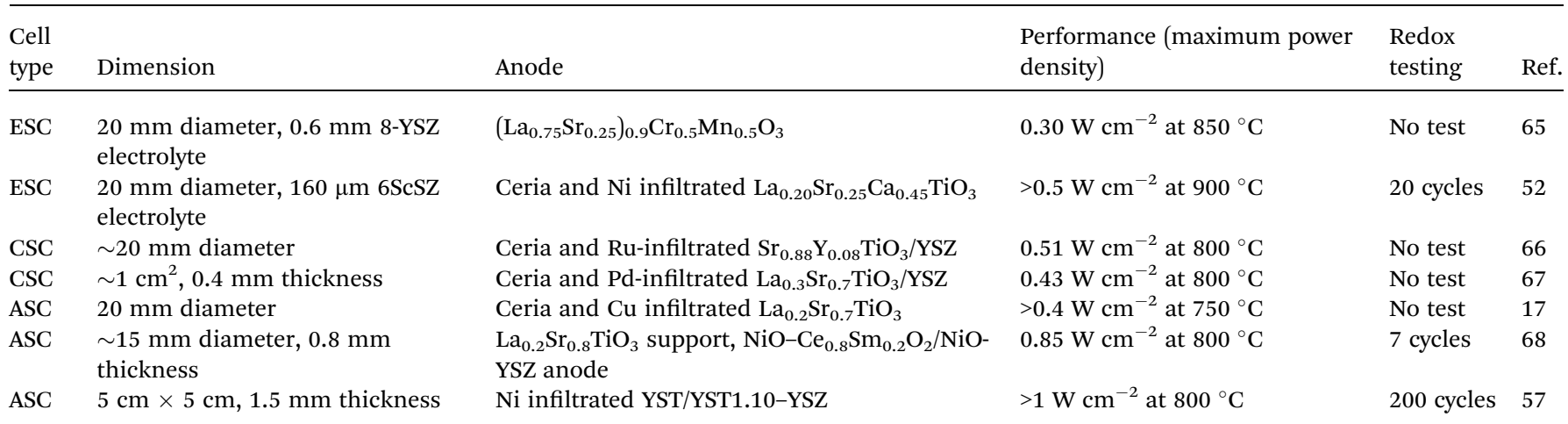




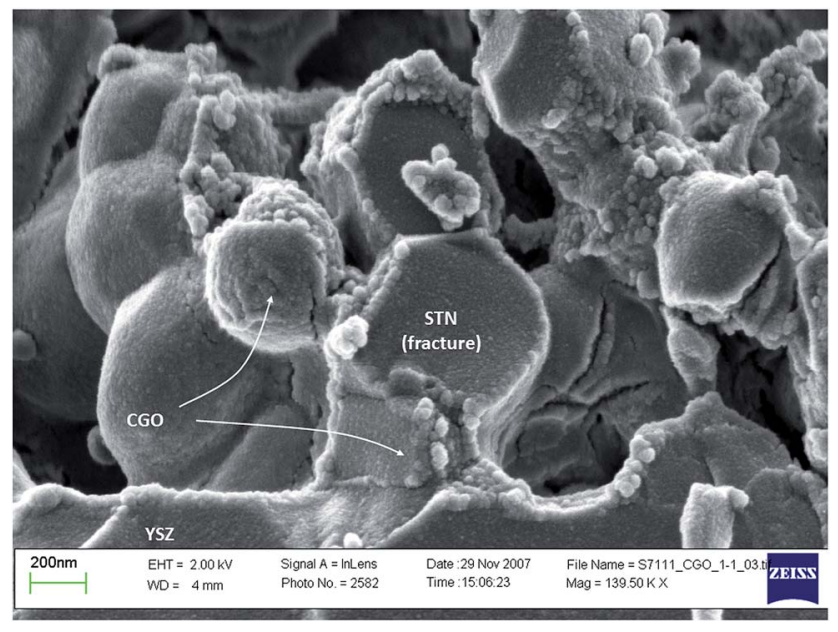

Fig. 16 SEM micrograph of CGO-electrode after impregnation from an ethanol-based solution and pre-calcination at $350^{\circ} \mathrm{C}$ on STN-YSZ composite backbone. ${ }^{62}$

change resistance $\left(R_{\mathrm{S}}\right)$ between $2.7 \mathrm{~m} \Omega$ and $16 \mathrm{~m} \Omega$, when subjected to $\mathrm{p}\left(\mathrm{O}_{2}\right)$-variations from $10^{-20}$ to $\sim 10^{-15}$ bar, which corresponds to the $3 \%$ steam and $85 \%$ steam, respectively, at $800{ }^{\circ} \mathrm{C}$. The change is practically reversible in this range of oxygen partial pressures and may account for some of the $R_{\mathrm{S}}$ variations observed.

Very promising results have recently been obtained by infiltrating STN94 backbones with a combination of CGO and ruthentium. ${ }^{63}$ Negligible degradation was observed in $R_{\mathrm{s}}$ and $R_{\mathrm{p}}$ when testing for 200 hours in high steam atmosphere $(50 \%$ $\mathrm{H}_{2} \mathrm{O}, 50 \% \mathrm{H}_{2}$ ) at $850{ }^{\circ} \mathrm{C}$. In comparison, the Ni/CGO infiltrate combination gave rise to a threefold increase in $R_{\mathrm{p}}$ in these conditions within the same time.

\section{Summary}

A-site deficient strontium titanates have the potential to replace nickel based cermet anodes in both electrolyte and anode supported cells. Their electronic conductivity under reducing conditions seems sufficient to provide adequate current collection. Their electrocatalytic activity towards fuel oxidation however is very limited, which necessitates the use of infiltrated nanosized catalysts. This approach has so far produced very promising fuel cell performances, with the addition of redox stability at low steam concentrations due to the absence of a structural nickel phase. Some of the fuel cell performances of Asite deficient strontium titanates have been summarised in Table 2. Literature reports on other ceramic anodes have been listed as well for comparison. It can be seen that strontium titanates show promising power outputs and seem to be redox stable. Literature reports on their long term stability is still scant however, so their durability in various configurations remains to be tested. Strontium titanates have also been reported to be sulphur tolerant, at least up to reasonable concentrations, ${ }^{\mathbf{8}, 64}$ but suitable catalysts will still have to be found that show a similar tolerance towards sulphur poisoning.

\section{Acknowledgements}

The authors gratefully acknowledge funding from the Fuel Cells and Hydrogen Joint Undertaking under grant agreement no. 256730 .

\section{References}

1 J. H. Hirschenhofer, D. B. Stauffer, R. R. Engleman and M. G. Klett, Fuel Cell Handbook, US Department of Energy, Morgantown WV, 4th edn, 1998.

2 P. Holtappels and U. Stimming, in Handbook of Fuel Cells, John Wiley \& Sons, Ltd, 2010.

3 M. Cimenti and J. M. Hill, Energies, 2009, 2, 377-410.

4 A. Mai, B. Iwanschitz, U. Weissen, R. Denzler, D. Haberstock, V. Nerlich, J. Sfeir and A. Schuler, ECS Trans., 2009, 25, 149158.

5 B. A. Haberman, C. Martinez Baca and T. R. Ohrn, ECS Trans., 2011, 35, 451-464.

6 H. Y. Tu and U. Stimming, J. Power Sources, 2004, 127, 284293.

7 S. McIntosh and R. J. Gorte, Chem. Rev., 2004, 104, 48454865.

8 Z. Cheng, J. H. Wang, Y. M. Choi, L. Yang, M. C. Lin and M. L. Liu, Energy Environ. Sci., 2011, 4, 4380-4409.

9 S. W. Zha, Z. Cheng and M. L. Liu, J. Electrochem. Soc., 2007, 154, B201-B206.

10 J. Malzbender, E. Wessel and R. W. Steinbrech, Solid State Ionics, 2005, 176, 2201-2203.

11 B. A. Boukamp, Nat. Mater., 2003, 2, 294-296.

12 A. Atkinson, S. Barnett, R. J. Gorte, J. T. S. Irvine, A. J. Mcevoy, M. Mogensen, S. C. Singhal and J. Vohs, Nat. Mater., 2004, 3, 17-27.

13 Q. X. Fu and F. Tietz, Fuel Cells, 2008, 8, 283-293.

14 T. Ishihara, Perovskite Oxide for Solid Oxide Fuel Cells, Springer, 2009.

15 N. G. Eror and U. Balachandran, J. Solid State Chem., 1981, 40, 85-91.

16 T. D. McColm and J. T. S. Irvine, Ionics, 2001, 7, 116-121.

17 C. D. Savaniu and J. T. S. Irvine, J. Mater. Chem., 2009, 19, 8119-8128.

18 J. C. Ruiz-Morales, J. Canales-Vazquez, C. Savaniu, D. Marrero-Lopez, W. Z. Zhou and J. T. S. Irvine, Nature, 2006, 439, 568-571.

19 T. Kolodiazhnyi and A. Petric, J. Electroceram., 2005, 15, 5-11. 20 U. Balachandran and N. G. Eror, J. Electrochem. Soc., 1982, 129, 1021-1026.

21 D. N. Miller and J. T. S. Irvine, J. Power Sources, 2011, 196, 7323-7327.

22 B. F. Flandermeyer, A. K. Agarwal, H. U. Anderson and M. M. Nasrallah, J. Mater. Sci., 1984, 19, 2593-2598.

23 D. N. Miller and J. T. S. Irvine, ECS Trans., 2007, 7, 14471454.

24 J. Canales-Vazquez, W. Z. Zhou and J. T. S. Irvine, Ionics, 2002, 8, 252-255.

25 V. Vashook, L. Vasylechko, H. Ullmann and U. Guth, Solid State Ionics, 2003, 158, 317-325. 
26 P. R. Slater, D. P. Fagg and J. T. S. Irvine, J. Mater. Chem., 1997, 7, 2495-2498.

27 R. Moos and K. H. Härdtl, J. Am. Ceram. Soc., 1997, 80, 25492562.

28 P. Blennow, PhD thesis, Lund University, 2007.

29 P. Blennow, K. K. Hansen, L. R. Wallenberg and M. Mogensen, Electrochim. Acta, 2006, 52, 1651-1661.

30 L. F. Zagonel, N. Barrett, O. Renault, A. Bailly, M. Baeurer, M. Hoffmann, S. J. Shih and D. Cockayne, Surf. Interface Anal., 2008, 40, 1709-1712.

31 M. B. Park and N. H. Cho, Solid State Ionics, 2002, 154, 175181.

32 S. J. Shih, S. Lozano-Perez and D. J. H. Cockayne, J. Mater. Res., 2010, 25, 260-265.

33 Y. M. Chiang and T. Takagi, J. Am. Ceram. Soc., 1990, 73, 3278-3285.

34 S. Y. Chung, S. J. L. Kang and V. P. Dravid, J. Am. Ceram. Soc., 2002, 85, 2805-2810.

35 A. Ianculescu, A. Braileanu, M. Zaharescu, S. Guillemet, I. Pasuk, J. Madarasz and G. Pokol, J. Therm. Anal. Calorim., 2003, 72, 173-180.

36 D. Neagu and J. T. S. Irvine, Chem. Mater., 2010, 22, 50425053.

37 P. Pasierb, S. Komornicki and M. Rekas, J. Phys. Chem. Solids, 1999, 60, 1835-1844.

38 D. Burnat, A. Heel, L. Holzer, E. Otal, D. Kata and T. Graule, Int. J. Hydrogen Energy, 2012, 37, 18326-18341.

39 Q. Ma, F. Tietz, D. Sebold and D. Stover, J. Power Sources, 2010, 195, 1920-1925.

40 O. A. Marina, N. L. Canfield and J. W. Stevenson, Solid State Ionics, 2002, 149, 21-28.

41 S. Q. Hui and A. Petric, J. Electrochem. Soc., 2002, 149, J1-J10.

42 S. Hashimoto, F. W. Poulsen and M. Mogensen, J. Alloys Compd., 2007, 439, 232-236.

43 S. G. Cho and P. F. Johnson, Ferroelectrics, 1992, 132, 115127.

44 P. Blennow, A. Hagen, K. K. Hansen, L. R. Wallenberg and M. Mogensen, Solid State Ionics, 2008, 179, 2047-2058.

45 Q. X. Fu, F. Tietz, D. Sebold, S. W. Tao and J. T. S. Irvine, J. Power Sources, 2007, 171, 663-669.

46 Q. L. Ma, F. Tietz and D. Stover, Solid State Ionics, 2011, 192, 535-539.

47 N. F. Mott, Rev. Mod. Phys., 1968, 40, 677-683.
48 M. T. Colomer and J. R. Jurado, J. Solid State Chem., 2002, 165, 79-88.

49 D. Sarantaridis, R. A. Rudkin and A. Atkinson, J. Power Sources, 2008, 180, 704-710.

50 A. D. Aljaberi and J. T. S. Irvine, J. Mater. Chem. A, 2013, 1, 5868-5874.

51 D. Neagu and J. T. S. Irvine, Chem. Mater., 2011, 23, 16071617.

52 M. C. Verbraeken, B. Iwanschitz, A. Mai and J. T. S. Irvine, J. Electrochem. Soc., 2012, 159, F757-F762.

53 A. Yaqub, C. Savaniu, N. K. Janjua and J. T. S. Irvine, J. Mater. Chem. A, 2013, 1, 14189-14197.

54 X. Zhou, N. Yan, K. T. Chuang and J. Luo, RSC Adv., 2014, 4, 118-131.

55 M. D. Gross, J. M. Vohs and R. J. Gorte, Electrochem. SolidState Lett., 2007, 10, B65-B69.

56 S. Lee, G. Kim, J. M. Vohs and R. J. Gorte, J. Electrochem. Soc., 2008, 155, B1179-B1183.

57 Q. L. Ma, F. Tietz, A. Leonide and E. Ivers-Tiffee, Electrochem. Commun., 2010, 12, 1326-1328.

58 D. Simwonis, H. Thulen, F. J. Dias, A. Naoumidis and D. Stover, J. Mater. Process. Technol., 1999, 93, 107-111.

59 A. Leonide, Y. Apel and E. Ivers-Tiffee, ECS Trans., 2009, 19, 81-109.

60 P. Blennow, K. K. Hansen, L. R. Wallenberg and M. Mogensen, ECS Trans., 2008, 13, 181-194.

61 A. M. Hussain, J. V. T. Hogh, T. Jacobsen and N. Bonanos, Int. J. Hydrogen Energy, 2012, 37, 4309-4318.

$62 \mathrm{P}$. Blennow, STN94 - YSZ composite backbone with CGO infiltration, ed. K. Agersted, 2010.

63 T. Ramos, S. Veltze, B. R. Sudireddy and P. Holtappels, ECS Electrochem. Lett., 2014, 3, F5-F6.

64 R. Mukundan, E. L. Brosha and F. H. Garzon, Electrochem. Solid-State Lett., 2004, 7, A5-a7.

65 S. Tao, J. T. S. Irvine and J. A. Kilner, Adv. Mater., 2005, 17, 1734-1737.

66 H. Kurokawa, L. M. Yang, C. P. Jacobson, L. C. De Jonghe and S. J. Visco, J. Power Sources, 2007, 164, 510-518.

67 G. Kim, M. D. Gross, W. Wang, J. M. Vohs and R. J. Gorte, J. Electrochem. Soc., 2008, 155, B360-B366.

68 M. R. Pillai, I. Kim, D. M. Bierschenk and S. A. Barnett, J. Power Sources, 2008, 185, 1086-1093. 